\title{
Rewiring of the Serotonin System in Major Depression
}

\author{
Faranak Vahid-Ansari and Paul R. Albert* \\ Ottawa Hospital Research Institute (Neuroscience), University of Ottawa Brain and Mind Research Institute, Ottawa, ON, \\ Canada
}

Serotonin is a key neurotransmitter that is implicated in a wide variety of behavioral and cognitive phenotypes. Originating in the raphe nuclei, $5-\mathrm{HT}$ neurons project widely to innervate many brain regions implicated in the functions. During the development of the brain, as serotonin axons project and innervate brain regions, there is evidence that $5-\mathrm{HT}$ plays key roles in wiring the developing brain, both by modulating $5-\mathrm{HT}$ innervation and by influencing synaptic organization within corticolimbic structures. These actions are mediated by 14 different 5-HT receptors, with region- and cell-specific patterns of expression. More recently, the role of the $5-\mathrm{HT}$ system in synaptic re-organization during adulthood has been suggested. The 5-HT neurons have the unusual capacity to regrow and reinnervate brain regions following insults such as brain injury, chronic stress, or altered development that result in disconnection of the 5-HT system and often cause depression, anxiety, and cognitive impairment. Chronic treatment with antidepressants that amplify 5-HT action, such as selective serotonin reuptake inhibitors (SSRIs), appears

OPEN ACCESS

Edited by: Reza Rahimian,

McGill University, Canada

Reviewed by:

Luc Maroteaux,

INSERM U839 Institut du Fer à Moulin

(IFM), France

Bruno Pierre Guiard,

Université de Toulouse, France

*Correspondence:

Paul R. Albert

palbert@uottawa.ca

Specialty section: This article was submitted to Molecular Psychiatry, a section of the journal

Frontiers in Psychiatry

Received: 26 October 2021 Accepted: 17 November 2021 Published: 16 December 2021

Citation: Vahid-Ansari F and Albert PR (2021) Rewiring of the Serotonin System in Major Depression.

Front. Psychiatry 12:802581. doi: 10.3389/fpsyt.2021.802581 to accelerate the rewiring of the 5-HT system by mechanisms that may be critical to the behavioral and cognitive improvements induced in these models. In this review, we survey the possible $5-\mathrm{HT}$ receptor mechanisms that could mediate $5-\mathrm{HT}$ rewiring and assess the evidence that $5-\mathrm{HT}$-mediated brain rewiring is impacting recovery from mental illness. By amplifying 5-HT-induced rewiring processes using SSRIs and selective 5-HT agonists, more rapid and effective treatments for injury-induced mental illness or cognitive impairment may be achieved.

Keywords: serotonin, neuroplasticity, antidepressant (AD), serotonin receptors, axonal guidance and plasticity

\section{INTRODUCTION}

Major Depressive Disorder (MDD) is characterized by a persistent low mood as a core symptom. The prevalence of depression is about 1 in 5 of the general population, affecting nearly 300 million people worldwide (1), and its prevalence has increased during the COVID-19 pandemic (2). The most recent global data place MDD as the third greatest source of disability, after low back pain and headache disorders (3). The currently available antidepressant drugs (ADs) have several disadvantages, including delayed efficacy (4-8 weeks) (4), numerous adverse effects that reduce tolerability (0.64- to 0.83 -fold) and modest efficacy (1.15- to 1.55 -fold) compared to placebo $(5,6)$ that limit therapeutic effectiveness to $\sim 30 \%$ remission (7). Among approved ADs, selective serotonin reuptake inhibitors (SSRIs) are the first-line treatment, and almost all target 5-HT and other monoamine systems (8). However, it is not fully understood why, despite brain levels of serotonin increasing with hours after SSRI administration, behavioral improvement takes weeks to be observed. This delay might reflect neuro-adaptive changes in pre-and post-synaptic cells, including long-term changes in gene expression, protein translation, 
or ultimately in neuroplasticity $(9,10)$. As it is diagnosed by a diversity of symptoms in the absence of biomarkers, major depression remains heterogeneous. A better understanding of the mechanism/s underlying the development of depression and its phenotypes will be critical to develop a more efficient, rational clinical approach to targeted treatment $(10,11)$.

Unraveling the pathophysiology of depression is a complex challenge. Not only are syndromes heterogeneous and the etiology diverse, but important symptoms such as guilt and suicidality cannot be reproduced in animal models. Nevertheless, other symptoms like anxiety, anhedonia, or behavioral despair have been modeled in animals (12-15), and these, together with clinical data, are providing insight into the neurobiology of mood disorders $(16,17)$ and antidepressant action (18). Recent studies combining behavioral, molecular, and functional imaging in transgenic mice have revealed that alterations in the functional connectivity of specific subpopulations of neurons forming a neural circuit result in depression-like behaviors (1923). Understanding the underlying causes of these functional changes might offer a crucial new direction for the development of novel treatments for MDD in humans.

\section{SEROTONIN AXON HYPOTHESIS IN DEPRESSION}

In pre-clinical and clinical studies, deficits in serotonergic transmission including reductions in serotonin (5hydroxytryptamine, 5-HT) neurons and their projections and increases in 5-HT autoinhibition have been associated with MDD and also with impaired responses to antidepressants (24-36). 5-HT is a monoamine neurotransmitter found mainly in blood platelets and the central nervous system (CNS) in animals and humans. It is widely implicated in mood, emotion, and happiness (37). The monoamine-serotonin hypothesis for depression was proposed in the 1960s suggesting that brain deficiency of monoamines, including 5-HT, triggers the onset of depression (38-40). It continues to guide research into the causes and treatments for depression, anxiety, and other mental illnesses.

\section{The 5-HT System}

The 5-HT neurons originating in the raphe midbrain innervate several regions of the brain (41-43). In 5-HT neurons, the enzyme tryptophan hydroxylase type 2 (TPH2) converts the amino acid tryptophan to 5-hydroxytryptophan (5-HTP) to catalyze the rate-limiting step in 5-HT biosynthesis (44-46). Subsequently, the L-aromatic amino acid decarboxylase (AADC) enzyme generates 5-HT. Alterations in 5-HT neurotransmission have been implicated in the pathophysiology of depression and its treatment. Based on clinical evidence that depressive symptoms improve following specific blockade of the 5HT transporter (5-HTT) (47), early research focused on the uptake site at the terminal targets (48). The forebrain projecting raphe nuclei include the dorsal (DRN) and median (MRN) raphe and contain a diversity of 5-HT and non-5-HT neurons, identified using viral-genetic, immunohistochemistry and electrophysiology methods (49-51). For example, a small population of 5-HT immune-positive cells are not co-labeled with 5-HT1A receptors $(52,53)$ while some non-5-HT cells (such as GABA neurons) are co-labeled (52). Some 5-HT neurons coexpress vesicular glutamate transporter-3 conferring glutamate neurotransmission and are implicated in anxiety behavior (54). Importantly, different projections of these neurons to target regions may confer stress susceptibility, depression or anxiety behaviors $(36,55,56)$. Thus, the distinct properties of select 5HT neuronal populations may confer behavioral phenotype and response to stress or injury.

In addition to developmental innervation, a unique capacity of the 5-HT system to regenerate or alter its innervation of brain regions has been observed after neurotoxin, traumatic or ischemic brain damage in rodents (57-64). Changes in 5-HT innervation have also been observed in non-lesion conditions such as repeated stress rodent models of depression $(65,66)$ and Parkinsonism in rodents (67) and primates (68). In post-mortem brain tissue from human depressed subjects, a reduction in 5-HT innervation has also been seen (32), although the functional role of these changes remains unclear.

The extensive ascending and descending 5-HT network projects throughout the brain and spinal cord making synaptic or non-synaptic contacts that release 5-HT (69-71). Actions of 5HT are mediated by at least 14 different receptor subtypes (72). It is believed that 5-HT axons prenatally initiate axon outgrowth concomitant with the onset of 5 -HT synthesis $(73,74)$. 5-HT axons form and grow in a targeted manner through guided pathfinding and arborization over several weeks. The 5-HT rich brain areas include cortical and sub-cortical regions. In addition, sensitive HPLC measurements of 5-HT and metabolites have shown that the metabolic activity of 5-HT fibers extending from DRN and MRN is parallels the tissue content of 5-HT (75). Therefore, it is expected that the alterations in 5-HT axons are associated with concomitant changes in 5-HT levels in the same brain region.

\section{Development of 5-HT Projections}

A large body of studies has characterized the molecular determinants involved in the developmental mechanisms targeting raphe 5-HT projections to the forebrain, proposing that alterations in these processes may predispose to mood disorders (74). Many of the transcription factors in the 5HT gene regulatory network required for differentiation and maintenance of 5-HT neuronal subgroups have been extensively characterized, including Lmx1B, Pet-1/FEV, and others $(76,77)$. These factors may also be involved in axonal outgrowth as shown for Lmx1B (78); conditional deletion of Lmx1B in 5-HT neurons resulted in the loss of axonal projections to the forebrain and spinal cord in mice. Cytoskeleton-associated proteins growthassociated protein 43 (GAP-43) and a microtubule-associated protein, stable tubule only polypeptide (STOP) are also required for the growth and elongation of the 5-HT axons (76). In normal mice, GAP-43 is prenatally expressed on growing 5-HT axons; but in GAP-43 knockout mice, there is a loss of 5-HT immunoreactive innervation of the cortex and hippocampus (79). In the STOP knockout mice, 5-HT levels, as well as 5-HTT density and terminals, are reduced in projection areas such as hippocampus, but increased in the raphe suggesting impaired 
trafficking of 5-HT vesicles resulting in deficits in hippocampal neurogenesis, reduced anxiety, increased helplessness, and impaired cognitive function $(80,81)$. Despite these deficits in 5-HT innervation, no significant difference in the number of dorsal raphe 5-HT neurons was observed in GAP-43 or in STOP knockouts compared to wild-type littermates. These results suggest that GAP-43 and STOP proteins are the key regulators of normal 5-HT outgrowth and innervation in healthy conditions.

Concerning 5-HT axon pathfinding and guidance, Fenstermaker et al. (82) reported that Wnt signaling to planar cell polarity components is required for anterior to posterior axon projection and for proper orientation of 5-HT cell bodies in the raphe nuclei, using mice lacking individual planar cell polarity genes (82). In addition, to guide the 5-HT axons along the midline and form the long-distance connectivity both Robo1/2 and Slit1/2 have key roles in the formation of major forebrain tracts as shown in knockout mouse lines $(83,84)$.

Genes involved in cell adhesion have also been implicated in 5-HT axonal outgrowth in development, including the Pcdh- $\alpha$ isoforms $(85,86)$. In particular, loss of the $\alpha \mathrm{C} 2$ isoform in serotonergic neurons, but not in 5-HT target brain regions, leads to abnormal projection and tiling of serotonergic axons, associated with increased depression-like behaviors (87). Interestingly, differentiation of induced pluripotent stem cells from SSRI-resistant compared to SSRI-responsive depressed patients to a serotonergic phenotype resulted in deficiencies in Pcdh- $\alpha$ expression and neurite outgrowth in vitro (88). More recently, an epigenome-wide association study of 150 monozygotic twins reported 428 differentially methylated genes associated with early-onset major depression, many of which are implicated in neurodevelopmental and cell adhesion genes including the protocadherin- $\alpha$ (Pcdh- $\alpha$ ) gene cluster (89). Taken together these studies implicate Pcdh- $\alpha$ genes in 5HT axonal outgrowth, major depression and response to SSRI antidepressants.

\section{VISUALIZING SEROTONIN AXONS}

\section{Early Markers}

Early studies of 5-HT projections in the brain relied on a relatively insensitive formaldehyde-induced immunofluorescence method to visualize 5-HT (90). Subsequent studies used labeling with $[3 \mathrm{H}] 5-\mathrm{HT}$ or immunostaining for 5HT to visualize 5-HT axons in brain sections $(71,91)$. However, more recent studies have used the more sensitive approach of 5-HTT immunostaining to visualize 5-HT projections (92). In addition, antibodies to TPH have been useful, particularly in human post-mortem brain sections (41). These studies have revealed that 5-HT fibers rarely branch and have a high density in many brain regions. A high density of 5-HT projections has been shown in the cerebral cortex and subcortical regions including striatum, hippocampus, entorhinal cortex and the NAc [core and caudal shell (93)]. In a single fiber, there are several specialized boutons or varicosities where $5-\mathrm{HT}$ is concentrated (91). It has been estimated that there are around $6 \times 10^{6}$ varicosities $/ \mathrm{mm}^{3}$ in the rat cortex. In addition, each cortical neuron may receive around 200 varicosities $(94,95)$. However, there is evidence of some non-5-HT producing neurons that transiently express
5-HTT during development in the thalamus identified by 5 -HT uptake and in situ hybridization for 5-HTT RNA (96). Using 5-HTT-cre mice to drive reporter gene expression, labeling was seen in dorsal thalamus, cingulate cortex, hippocampal CA3 neurons, retinal ganglion cells, superior olivary and cochlear nuclei during embryonic development and postnatally in medial prefrontal cortex (97). These studies suggest that neurons that lack TPH can take up 5-HT and in the thalamus can store the 5-HT in vesicles for co-transmission with glutamate. On the other hand, chronic SSRI-induced blockade of 5-HTT leads to uptake and release of 5-HT by the dopamine transporter in DA neurons $(98,99)$. Similar, l-DOPA treatment leads to DA uptake and release in 5-HT neurons (100), indicating cross-talk between monoamine systems at the level of co-transmission following chronic drug treatment.

\section{Non-synaptic 5-HT/Volume Transmission}

In addition to conventional synapses, serotonin is also released from varicosities into extracellular spaces with no target cell dendrites nearby $(70,101)$, a process termed volume transmission $(102,103)$. The non-synaptic release of 5-HT allows a paracrine transmission of serotonin to distal neurons and glia, particularly in the presence of 5-HT reuptake blockers, to activate highaffinity 5-HT receptors. Thus, both synaptic and non-synaptic 5-HT release may be implicated in the actions of raphe activation. As discussed below, activation by 5-HT of multiple 5-HT receptors engage several effector proteins to regulate neurite outgrowth, growth cone motility, synaptogenesis, and shape the dendritic spine and density in a wired brain.

The above examples illustrate that to identify 5-HT neurons and their projections it is important to combine different approaches. Recently, several genetic approaches using transgenic mice 5-HT-specific promoters (including 5-HTT, TPH2, Pet-1) to drive the expression of reporter genes (such as LacZ, YFP) have been used in combination with immunostaining for 5-HT markers (5-HT, 5-HTT, TPH2) to identify 5 -HT projections $(104,105)$. These labeling approaches have been combined with anterograde and retrograde labeling techniques (106) to further define at a macroscopic level the neuroanatomy of the 5-HT system (56, 107-111). For example, at the cellular level, dual retrograde tracing revealed that a small (10-20\%) proportion of neurons innervate both nucleus accumbens and medial prefrontal cortex (112). Single-cell biotin labeling has also been used to localize region-specific 5-HT/vGlut3 projections (113). These results indicate that single 5-HT neurons can innervate multiple brain regions.

\section{Visualizing 5-HT Synapses}

For high-resolution visualization of 5-HT synapses, electron microscopic (EM) studies (91) and 3D reconstruction of 5-HTTpositive axons have been used to map the 5-HT boutons located proximal to excitatory or inhibitory synapses in limbic brain regions $(114,115)$. Post-synaptic components of excitatory or inhibitory synapses form "triads". To finely dissect how 5-HT exerts its modulatory actions, asymmetrical synapses/excitatory triads were mostly localized in the hippocampus, cortex, $\mathrm{mPFC}$ while symmetrical synapse/inhibitory triads were enriched in the dorsal raphe nucleus (DR), ventral tegmental area (VTA), 
central and basolateral amygdala (CeA, BLA) $(116,117)$. The combination of both (excitatory-inhibitory) was observed in areas like thalamic regions, bed nucleus of stria terminalis (BNST), and nucleus accumbens (NAc) (91, 114, 115). The preferential proximity of 5 -HT boutons to neurochemical excitatory/inhibitory synapses could therefore suggest that serotonergic axons projecting to one area may preferentially target local glutamatergic, interneurons, or both to modulate their activity. For example, the preferential proximity of 5HT-positive axon terminals to GABA terminals engaged in symmetrical synapses in DR and amygdala sub-regions (CeA, BLA) suggests that 5-HT mainly modulates the activity of interneurons in DR and amygdala. In contrast, 5-HT axon terminals are mainly engaged in asymmetrical synapses in mPFC to modulate the activity of excitatory neurons. Therefore, alterations in 5-HT system activity which preferentially change the activity of different cell types in target brain regions could differentially impact behavioral output. Recently, using a semi-automated approach that combines immunohistochemistry and high-resolution confocal microscopy to label 5-HTT immunoreactive axons has allowed researchers to reconstruct the 5-HT axons in 3D through their distribution within limbic brain regions $(114,115)$. Using this approach, the changes in 5 -HT axon properties have been also determined in a model of post-stroke depression induced by focal ischemia in mice medial prefrontal cortex ( $\mathrm{mPFC}$ ), before and after treatment with chronic fluoxetine (64).

Imaging techniques have shown that the density and other features of 5-HT fibers can be altered during and after development. For example, Azmitia et al. (118) found that the density of serotonergic fibers is unusually high in the cerebral cortex of individuals suffering from autism spectrum disorders (118). In contrast, post-mortem studies in adult subjects showed that depression is associated with reduced 5-HT innervation of the orbitofrontal cortex in addition to the loss of hippocampal volume (32). Liu and Nakamura (65) reviewed the effects of chronic stress on regeneration of noradrenaline (NA) and 5-HT axons following NA or 5-HT neurotoxin in adult rats (65). They reported that, in contrast to NA axons, 5-HT axons are more dynamic in morphological plasticity as they are easily affected by stress and rapidly regenerate after damage. 5- $\mathrm{HT}$ axons also exert an inhibitory effect on NA axon regeneration. Furthermore, in a depression model induced by 9 -week administration of interferon- $\alpha$ to adult male Sprague-Dawley rats, the density of 5-HT-stained axons decreased specifically in the ventral medial prefrontal cortex and amygdala (119). Thus, using new imaging approaches could promote the early diagnosis and development of more effective treatments for depression based on the morphological plasticity of 5-HT axons.

\section{VOLUME TRANSMISSION: BEYOND SYNAPTIC COMMUNICATION IN THE WIRED BRAIN}

Recent scientific evidence has focused on the complexities of neurotransmitter (NT) communication in the wired brain.
In this regard, the importance and relevance of both fasttargeted synaptic and slow-non synaptic transmission has been recognized.

The concept of non-synaptic communication or volume transmission in the brain was proposed in the 1980s $(102,120)$, and shown for monoamines including 5-HT (117, 121). In 1994, Bjelke et al. showed indirect evidence that amphetamineinduced dopamine release may diffuse long distances following fiber tracts, possibly to the contralateral hemisphere (122). This is supported by the diffusion of Texas-Red-labeled dextran injection in the striatum, which diffuses along fiber tracts to the contralateral brain hemisphere (123). More recently, based on the half-life of dopamine it has been calculated that it might diffuse up to 7 microns (124). With newer, more sensitive indicators specific for dopamine and other monoamines (125), it may be possible to detect the diffusion of dopamine from non-synaptic release.

Using techniques such as receptor autoradiography, immunohistochemistry, and EM imaging has shown for monoamines a mismatch between the location of NTs relative to synaptic structures $(103,126,127)$. For example, Martin et al. (128) showed that $94 \%$ of tyrosine hydroxylase-positive boutons in macaque prefrontal cortex Area 10 had no identifiable synaptic association in non-human primates (129). Rice et al. (130) modeled dopamine release to show that the presence of dopamine outside of the synaptic zone in the nigrostriatal pathway could be due to the spillover from the synaptic cleft and release into the surrounding extracellular space. Dopamine concentration remains sufficiently high to activate extra-synaptic dopamine receptors on surrounding cells (130). Mapping studies using diverse techniques also identified varicosities filled with NT granules localized along the axons. This evidence supports the existence of NTs in a high volume in non-terminal axon segments. Rodent studies showed that the main action of modulatory NTs including acetylcholine, norepinephrine, dopamine, and serotonin in the brain is through volume transmission via non-synaptic contacts of varicosities within axons (126).

After the first evidence supporting the concept of volume transmission in dopamine release in the brain by Fuxe and Ungerstedt (131), similar approaches were used for the 5HT cell bodies located in dorsal raphe upon treatment of rats with 5-HT reuptake blocker clomipramine (132). The release of 5-HT from vesicles in the soma, dendrites, and/or axonal varicosities could also be independent of targeted synapses (133-135). More directly, parachloroamphetamineinduced non-synaptic somatodendritic release of 5-HT has been visualized using 3-photon microscopy of dorsal raphe sections (136). Somatodendritic and axonal release of 5-HT can be triggered by neuron depolarization, the stimulation of $\mathrm{L}$ type calcium channels, activation of glutamatergic receptors, and/or by activation of 5-HT2 receptors (137). Furthermore, somatodendritic 5-HT release can also regulate the rate of discharge of serotonergic neurons and their tonic activity, via somatodendritic 5-HT1A and 5-HT2B autoreceptors (29, $138,139)$. Nevertheless, direct evidence of 5-HT volume transmission-induced depression of 5-HT firing has not been 
reported (140). However, it has been recently shown that somatodendritic release of dopamine acting via D2 receptors autoinhibits the firing of the same neuron (141), suggesting a truly auto-regulatory system.

\section{AXONAL AND NEURITE OUTGROWTH: SEROTONIN RECEPTORS}

During development, differentiation of 5-HT neurons (e10.513 in rat) and outgrowth 5-HT projections is initiated early in embryonic development of the brain (e12-14 in rat) and continues well into post-natal development (p21 in rat) $(73,76$, $142,143)$. The availability of serotonin during embryonic to early post-natal developmental stages implicate serotonin signaling in directed axonal and neurite outgrowth during development (144, 145 ) and also in mediating neuroplasticity responses to external stimuli during and post-development (146). In this light, deletion of TPH2 to block neuronal 5-HT synthesis results in abnormal projections of 5-HT neurons both during development and in adults $(147-150)$. Serotonin can also accumulate in $(96,151)$ and affect the development of non-serotonergic neurons in cortex and hippocampus (147, 152-155). Vicenzi and Gasperini (156) recently found that exogenous serotonin acts as a guidance cue during axon pathfinding in sensory neurons in vitro, capable of concentration-dependent attraction (via 5-HT2A receptor) or repulsion (via 5-HT1B receptor) of growth cone motility (156). However, the role of endogenously released 5-HT gradients in axonal outgrowth in vivo remains to be assessed.

The actions of serotonin on target cells, including glutamate and GABA neurons, are mediated by a large family of 5HT receptors. Currently, genes for 14 receptors, including 13 distinct heptahelical G protein-coupled receptors (GPCRs) and one ligand-gated ion channel, have been identified. Based on their structural and downstream signaling characters, receptors are divided into seven distinct classes including 5-HT1-7 receptors $(72,157)$. The role of some key receptors in the 5-HT axonal transmission including axonal growth and axonal guidance is summarized below.

\section{5-HT1 Receptors}

The largest class of 5-HT receptors is the 5-HT1 receptor family characterized by an intronless coding sequence with five subtypes sharing $40-63 \%$ sequence homology $(72,157)$. The $5-\mathrm{HT} 1 \mathrm{~A},-1 \mathrm{~B},-1 \mathrm{D},-1 \mathrm{E}$ and $-1 \mathrm{~F}$ receptors are localized in a wide variety of brain regions and show distinct pharmacological characteristics. The 5-HT1A receptors are broadly expressed in cortex, limbic areas, raphe nuclei (on 5-HT neurons as autoreceptors), in extrapyramidal areas, such as the substantia nigra, caudate-putamen, and in the cerebellum during embryonic-early postnatal development (158-168). The 5-HT1A receptors have been also found on astrocytes $(169,170)$ to mediate neuroprotective actions (171).

Using in vivo studies, Azmitia et al. (172) showed that 5HT1A receptors have a key role in 5-HT-induced increases MAP2 and synaptophysin in the hippocampus, hypothalamus, parietal and temporal cortices, and the temporal pole (172). In vitro studies showed that 5-HT1A receptor stimulation decreased neurite outgrowth in cortical neurons (173), increased it in hippocampal cultures (174) while had no effect or inhibit outgrowth in serotonergic raphe neurons (175, 176). The 5-HT1A receptor can trigger diverse downstream signaling mechanisms that are region- and cell-specific and may mediate these actions $(177,178)$. 5-HT1A receptor coupling via G $\beta \gamma$ subunits reduces neuronal activity by opening potassium channels and closing calcium channels. However, the receptor is coupled primarily to Gi3 in 5-HT neurons and Gi2 in hippocampal neurons, which may underlie differential signaling and desensitization in these cells. While in 5-HT neurons, the 5-HT1A receptor appears to inhibit extracellular regulated protein kinase (ERK) ERK1/2 activity (179), it signals to activate it in developing and adult hippocampal neurons and may play roles in synaptogenesis (180). Recent studies implicate 5HT1A signaling through G $\beta \gamma$ and tyrosine kinase receptors to activate ACII (181), phospholipase C (PLC)/protein kinase C (PKC) (182), calcium-calmodulin-dependent protein kinase II (CAMKII) (183), and phosphatidylinositol 3'-kinase (PI3K)/Akt signaling (184) mediating synaptogenesis, dendrite outgrowth, cell survival. Thus, the 5-HT1A receptor appears to modify its signaling repertoire depending on the cell type (5-HT vs. post-synaptic neurons) and the developmental state of the neuron (178). Previous studies also showed the crucial role of serotonin in modulating the neuronal guidance cues to shape the connectome in the wired brain mediated by the 5 -HT1 family $(185,186)$. For example, $5-\mathrm{HT} 1 \mathrm{~B} / 1 \mathrm{D}$ receptor activation induces the growth and guidance of embryonic thalamocortical axons (187). In this process, axon responses to netrin-1 shift from attraction to repulsion during the cortical network shaping.

Cortical plasticity in adulthood can also be modified by 5-HT1 receptor activity. For example, chronic fluoxetine treatment induced a full recovery from monocular deprivation in adult rats by increasing brain-derived neurotrophic factor (BDNF) expression to reduce GABAergic activity in the visual cortex thus enhancing excitatory long-term potentiation (188). These actions of fluoxetine suggest that synaptic, possibly structural re-organization of the cortex can be induced in adulthood. Interestingly, these actions of fluoxetine were blocked by 5 -HT1A antagonist WAY-100635, implicating 5-HT1A-induced BDNF expression in adult cortical plasticity (189). It remains unclear whether similar 5-HT1-induced signaling to BDNF in the PFC may mediate synaptic reorganization implicated in the antidepressant actions of SSRIs as seen for rapidly acting antidepressants such as ketamine $(190,191)$.

\section{5-HT2 Receptors}

The 5-HT2 receptor subtypes including 5-HT2A-C share about $50 \%$ amino acid sequence identity and show similarities concerning molecular structure, pharmacology, and signal transduction pathways $(72,192)$. 5-HT2A receptor expression is widely observed in cortical areas (neocortex, entorhinal, and piriform cortex), olfactory tubercle, dentate gyrus, and several brainstem nuclei, motor cranial nerve nuclei, and the spinal cord ventral horn $(168,193)$. In vitro studies have shown that stimulation of 5 -HT2A receptors inhibits neurite 
growth in serotonergic neurons (176) while increasing neurite outgrowth in thalamic neurons (194), with no effects on cortical glutamatergic neurites (195). Recent studies by Vicenzi et al., (156) using a growth cone motility assay showed that serotonin is capable of acting as both attractive and repulsive guidance cue on its own axons via activation of 5-HT2A and 5-HT1B receptors, respectively (156). The low concentration of serotonin as $50 \mu \mathrm{M}$ induces attraction mediated by 5 -HT2A while twice this concentration elicits the repulsion through the stimulation of 5-HT1B. In agreement, high-resolution imaging of growth cones indicateds that differential signaling is involved. For these actions, 5-HT2A receptors signaled through their canonical pathways of endoplasmic reticulum-mediated calcium release and 5-HT1B through cAMP depletion.

\section{5-HT3 Receptors}

The 5-HT3 receptors, the only ligand-gated, non-selective cation channel 5-HT receptors, are expressed in the cerebral cortex, hippocampus, amygdala, and the solitary tract nucleus (196). The 5-HT3 receptor is not coupled to second-messenger cascades which makes it different from the other members of the 5HT receptor family. The expression of 5-HT3 receptors in neuroblasts during brain development has suggested that they may play a role in neuronal differentiation and development (197). However, there is debate regarding the role of 5-HT3 receptors in neurite outgrowth, as 5-HT3 receptors may enhance dendritic spine formation in thalamic cultures (194), but not neurite outgrowth (198). For example, 5-HT3 receptors form a complex with the light chain of microtubule-associated protein 1B (MAP1B) and the tubulin cytoskeleton in dendrites and growth cones of hippocampal neurons during developmental (199). However, knockout of 5-HT3 receptor did not alter dendritic spines at baseline or following long-term depression in adult mice (200).

\section{5-HT4 Receptors}

5-HT4 receptors are implicated in the regulation of multiple physiological processes and are highly expressed in various regions of the limbic and in several basal ganglia components of the rodent brain (201-203). In transfected cell lines and primary neurons, 5-HT4 receptors primarily induce the cAMP pathway via Gs proteins (204), but can also signal to ERK activation via SRC protein kinase (205). In vitro studies showed that 5-HT4 receptor activation induces decreases in neurite outgrowth (206). By contrast, studies in the hippocampus also showed that 5-HT4 receptor activation enhances learning-induced hippocampal dendritic spine formation in vivo (207). 5-HT4 receptor activation was shown to rapidly trigger dendritic spine formation in hippocampal neurons (208) via G13-RhoA signaling pathway (209). Pharmacological studies showed that agonist-induced 5HT4 receptor activation inhibits basal synaptic transmission and theta-burst LTP via GABAergic activation (210), while enhancing low-frequency induced hippocampal LTD (211). In contrast, 5-HT4 antagonist induced thalamostriatal spike timing-dependent LTD expression (212), while blocking 5HT-induced late LTP in the amygdala (213). Therefore, the 5-HT4 receptor has a role in modulating synaptic transmission via the regulation of long-term plasticity. In addition, 5-HT4 receptors mediate SSRI-induced "dematuration" of adult hippocampal granule neurons implicated in behavioral actions $(214,215)$. Furthermore, the antidepressant actions of SSRI in depression models requires 5-HT4 receptors (216, 217). Interestingly 5-HT4 receptors have been implicated in rapid induction of hippocampal neurogenesis and rapid antidepressant actions (218). Since the above studies have used systemic 5-HT4 ligands, global 5-HT4 knockout mice, or slice preparations, the relative roles of 5-HT4 induced actions on region-specific synaptic transmission, neuroplasticity, and neurogenesis in its behavioral and cognitive actions remains to be clarified using tissue-specific gene knockout or drug delivery approaches.

\section{5-HT6 Receptors}

The 5-HT6 receptors are expressed in diverse brain areas including the olfactory tubercle, cortex, dorsal and ventral striatum, hippocampus, amygdala as well as choroid plexus (219-221), and are implicated in schizophrenia, anxiety, and Alzheimer's disease (222). The 5-HT6 receptor activates ACs by coupling to Gs proteins (223), interacts with Fyn kinase to mediate ras-MEK-ERK1/2 signaling (224, 225), and with Jab1 to couple to the transcription factor c-Jun (226). In vivo studies in the developing cortex have implicated 5-HT6 receptors localized in dendritic cilia in dendritic outgrowth and neuronal differentiation, signaling via the Fyn pathway (227, 228). Actions of 5-HT6 signaling on neurite outgrowth involve constitutive activation of the receptor by $\mathrm{cdk} 5$, which can be blocked by 5 -HT6 antagonist $(229,230)$. In addition, 5-HT6 signaling regulates migration of cortical pyramidal neurons and interneurons during development $(231,232)$. More recently, 5-HT6-/- mice have been shown to have altered in vivo dendritic and neuronal morphology, increased neuronal excitability, and increased anxiety and cognitive impairment phenotypes (233). In terms of neurotransmission, agonistinduced 5-HT6 receptor activation acutely increases expression of BDNF and Arc in cortical and hippocampal brain areas (234) and in the hippocampal CA1 area increases GABA release and decreases synaptic plasticity $(235,236)$. Using a 5-HT6 receptor antagonist increases the levels of glutamate, acetylcholine, and catecholamine in the frontal cortex and hippocampus and results in enhanced excitatory neurotransmission. 5HT6 receptor antagonists inhibit the mTOR complex, which promotes neuronal survival and increases neurite outgrowth (237). This 5-HT6 modulation of the mTOR complex provides a promising target to treat anxiety, schizophrenia, and Alzheimer's disease (230). Although an increasing body of studies indicates that acute effects of both 5-HT6 receptor antagonists and agonists elicit improvement in depression and anxiety observed in the preclinical models (238), the underlying mechanisms are not clear. Given the importance of 5-HT6 receptors in cortical development, this receptor may also play a role in the recovery and regeneration of 5-HT projections lost in adulthood and associated with cognitive impairment (239) and depression (238). 


\section{5-HT7 Receptors}

The 5-HT7 receptors are involved in the sleep-wake cycle, body temperature, depression-like behavior and the processes of learning and memory (240-242). In the brain, they are mainly expressed in the thalamus, hypothalamus, hippocampus, prefrontal cortex, amygdala, lateral habenula, raphe nuclei, and the suprachiasmatic nucleus $(240,243,244)$. 5-HT7 receptors couple to $\mathrm{G} \alpha \mathrm{s}$ (245) and $\mathrm{G} \alpha 12$ (206). G $\alpha 12 / 13$ proteins signal to activate $\mathrm{JNK}, \mathrm{G}$ protein signaling proteins (RGS) (246), non-receptor tyrosine kinases (nRTK) to signal to the Rho family of small GTPases that promote neurite extension and branching $(247,248)$. In vitro studies reported the involvement of 5-HT7 receptors in neurite outgrowth, spinoand synaptogenesis in young neurons, and increases in axon outgrowth via mTOR, Cdc4, to regulate actin filaments dynamics and metalloproteinase induced synaptic remodeling (249-252). Interestingly, in postnatal development, the 5-HT7 receptor is co-expressed with 5-HTT on PFC neurons and mediates PFC projections to the DRN implicated in development of anxiety and depression like phenotypes in mice treated postnatally with SSRI (253). The role of 5-HT7 receptors in modifying PFC projections during adulthood remains to be elucidated.

\section{TRIGGERING 5-HT AXONAL AND NEURITE OUTGROWTH}

How is spontaneous 5-HT axonal outgrowth triggered? By analogy with activity-dependent neuroplasticity following stroke $(254,255)$, it is hypothesized that regrowth of 5-HT axons after an injury is driven by the activity of the affected 5-HT neurons. For example, following a stroke to the left mPFC, we have observed a 3-4 fold chronic activation ( $\mathrm{FosB}^{+}$cells) of dorsal raphe $5-\mathrm{HT}$ and vGlut3-positive neurons that is maintained after fluoxetine treatment (256). Since full recovery of 5-HT innervation and behavior is only seen after chronic fluoxetine treatment (64), this suggests that fluoxetine-induced augmentation of 5-HT levels at target regions is critical for 5-HT innervation to mediate behavioral and cognitive recovery. This implicates 5HT autoregulatory effects on its own axons in affected area, which may be mediated via 5-HT receptor signaling (as discussed above). The importance of 5-HT neuronal activation is suggested by deep brain stimulation of the mPFC in rats subjected to chronic social defeat. Increasing cortical drive to the raphe induced dendritic remodeling of 5-HT neurons to restore their activity, resulting in increased size and number of presynaptic 5HT terminals in the hippocampus (66). The released 5-HT likely signals through a variety of 5-HT receptors on 5-HT projections, local glial cells and target neurons to ultimately restore behavior as discussed above.

\section{DETECTING 5-HT AXONAL AND NEURITE OUTGROWTH IN HUMANS}

Does the loss of 5-HT innervation occur in clinical depression, and can it be reversed by chronic SSRI treatment? The problem is how to visualize 5-HT innervation in depressed patients. One method is to use the 5-HTT as a biomarker for 5-HT innervation. In post-mortem brain, several regions show reduced 5-HTT staining including the ventral PFC, which was associated with depression and childhood maltreatment (257, 258). More specifically, visualization and quantification of 5-HTT-immunopositive processes have shown a reduction in the length of 5-HT axons in orbitofrontal cortex from depressed subjects (32). This region integrates multi-model sensory input to drive reward and affective behavior (259), and its activity is inversely correlated with the severity of depression (260). In living patients, this has been evaluated in positron emission tomography studies using ligands such as ${ }^{11} \mathrm{C}$-DASB. This is supported by the loss of DASB binding in cortex and striatum following MCAO in rats, with a gradual recovery over 3 weeks (128), similar to the time course that we observed in post-ischemic mice (64). Using ${ }^{11} \mathrm{C}$-DASB to label 5-HTT, a reduced 5-HTT ratio between dorsal raphe/ventral striatum was seen in unmedicated depressed compared to healthy controls, suggesting reduced 5-HT innervation to this reward processing center (261). By contrast, no difference in 5-HTT levels was seen in recovered depressed subjects compared to controls (262), whereas alterations are seen in several brain areas of severely depressed patients (263). Restorative effects of antidepressant treatment on 5-HTT levels have also been reported. In depressed subjects, altered 5-HTT ratio between median raphe to bilateral habenula, amygdala-hippocampus and subgenual cingulate cortex predicted treatment response (264). In bipolar depression, lower levels of 5-HTT and 5-HT1A predicted response and remission to 8 -wk lithium treatment (265). Taken together, these studies suggest that alterations in 5-HTT levels, perhaps due to altered 5-HT innervation, are associated with depression and response to SSRIs. However, these changes could simply reflect changes in 5-HTT expression level, rather than 5-HT innervation. Functional connectivity studies using fMRI with the raphe as a seed may provide addition evidence of impaired 5-HT projections, as raphe connectivity strength mirrors 5-HTT levels in healthy controls (266). Acute tryptophan depletion decreased functional connectivity of the raphe to right pregenual anterior cingulate cortex in SSRIresistant depressed subjects, but increased raphe-left thalamus connectivity in SSRI-responders, suggesting that increased 5HT innervation correlates with SSRI response (267). Taken together, these studies indicate a deficiency in 5-HT innervation occurs in major depression and can be modified by chronic treatment in SSRI-responders. The importance in behavior of these neuroplasticity changes remains to be addressed but developing strategies to enhance 5-HT neuroplasticity may provide a more robust antidepressant response. Using models of SSRI-resistant depression such as the cF1ko mice (10), it will be possible to elucidate whether changes in 5-HT axons associated with depression and anxiety are unresponsive to fluoxetine and develop alternative or augmentation therapies to efficiently enhance the activity of 5-HT system and axonal plasticity to treat SSRI-resistant patients.

\section{CONCLUSION}

Although not extensively studied, increasing evidence is indicating that deficiencies in 5-HT innervation associated 
with development, chronic stress or brain injury may lead to depression (10). Furthermore, the 5-HT system is capable of regenerating lost projections. Particularly after injury or chronic stress, 5-HT rewiring is induced during recovery (62), and can be enhanced by SSRI treatment or activation of 5-HT neurons $(64,66)$. While 5-HT rewiring correlates with recovery $(66,256)$, it remains to be directly addressed how important this mechanism is for recovery in rodent models. In humans, some research shows alterations in 5-HTT labeling in post-mortem OFC associated with major depression (32). Further studies are needed to determine what other brain regions might be affected, how early, and the effect of successful treatment on these projections.

Exactly how SSRIs might trigger reinnervation remains unclear. For example, 5-HT1A receptor-mediated induction of BDNF has been implicated in cortical synaptic plasticity, but whether BDNF mediates changes in innervation is unclear (188). However, abundant evidence indicates that several 5-HT receptors have actions to enhance synaptic plasticity and the formation of new synaptic connections. Direct activation of some of these receptors has been shown to mediate antidepressant

\section{REFERENCES}

1. WHO. Depression and Other Common Mental Disorders: Global Health Estimates. (Geneva, Switzerland: World Health Organization). (2017).

2. Ettman CK, Abdalla SM, Cohen GH, Sampson L, Vivier PM, Galea S. Prevalence of depression symptoms in US adults before and during the COVID-19 pandemic. JAMA Netw Open. (2020) 3:e2019686. doi: 10.1001/jamanetworkopen.2020.19686

3. Global Burden of Disease: Injury, Incidence, Prevalence Collaborators. Global, regional, and national incidence, prevalence, and years lived with disability for 354 diseases and injuries for 195 countries and territories, 19902017: a systematic analysis for the Global Burden of Disease Study 2017. Lancet. (2018) 392:1789-858. doi: 10.1016/S0140-6736(18)32279-7

4. Nierenberg AA, Farabaugh AH, Alpert JE, Gordon J, Worthington JJ, Rosenbaum JF, et al. Timing of onset of antidepressant response with fluoxetine treatment. Am J Psychiatry. (2000) 157:1423-8. doi: 10.1176/appi.ajp.157.9.1423

5. Cipriani A, Furukawa TA, Salanti G, Geddes JR, Higgins JP, Churchill $\mathrm{R}$, et al. Comparative efficacy and acceptability of 12 new-generation antidepressants: a multiple-treatments meta-analysis. Lancet. (2009) 373:746-58. doi: 10.1016/S0140-6736(09)60046-5

6. Cipriani A, Furukawa TA, Salanti G, Chaimani A, Atkinson LZ, Ogawa $\mathrm{Y}$, et al. Comparative efficacy and acceptability of 21 antidepressant drugs for the acute treatment of adults with major depressive disorder: a systematic review and network meta-analysis. Lancet. (2018) 391:135766. doi: 10.1016/S0140-6736(17)32802-7

7. Trivedi MH, Fava M, Wisniewski SR, Thase ME, Quitkin F, Warden $D$, et al. Medication augmentation after the failure of SSRIs for depression. N Engl J Med. (2006) 354:1243-52. doi: 10.1056/NEJMoa0 52964

8. Artigas F, Bortolozzi A, Celada P. Can we increase speed and efficacy of antidepressant treatments? Part I: General aspects and monoamine-based strategies. Eur Neuropsychopharmacol. (2018) 28:445-56. doi: 10.1016/j.euroneuro.2017.10.032

9. Krishnan V, Nestler EJ. The molecular neurobiology of depression. Nature. (2008) 455:894-902. doi: 10.1038/nature07455

10. Vahid-Ansari F, Zhang M, Zahrai A, Albert PR. Overcoming resistance to selective serotonin reuptake inhibitors: targeting serotonin, actions in some tests and certain models of depression. However, it remains unclear how effective these compounds will be in human depression.

By coordinately targeting 5-HT activity, 5-HT release and 5HT receptor-induced synaptic remodeling may provide a more effective strategy to treat depression, even in treatment-resistant depressed subjects.

\section{AUTHOR CONTRIBUTIONS}

FV-A conceived and wrote the first draft, corrected revised version, and approved the final version. PA conceived and revised the first draft and finalized the manuscript. Both authors contributed to the article and approved the submitted version.

\section{FUNDING}

This research was supported by a University of Ottawa Brain and Mind Research Institute Fellowship to FV-A and operating grant funding from the Canadian Institutes of Health Research to PA (PJT168948), and support for open access fees from the University of Ottawa Library.
Serotonin-1A receptors and adult neuroplasticity. Front Neurosci. (2019) 13:404. doi: 10.3389/fnins.2019.00404

11. Bortolozzi A, Celada P, Artigas F. Novel therapeutic strategies in major depression: focus on RNAi and ketamine. Curr Pharm Des. (2014) 20:384860. doi: 10.2174/13816128113196660137

12. Schechter MD, Chance WT. Non-specificity of "behavioral despair" as an animal model of depression. Eur J Pharmacol. (1979) 60:13942. doi: 10.1016/0014-2999(79)90212-7

13. Cryan JF, Mombereau C, Vassout A. The tail suspension test as a model for assessing antidepressant activity: review of pharmacological and genetic studies in mice. Neurosci Biobehav Rev. (2005) 29:571625. doi: 10.1016/j.neubiorev.2005.03.009

14. Castagné V, Moser P, Roux S, Porsolt RD. Rodent models of depression: forced swim and tail suspension behavioral despair tests in rats and mice. Curr Protoc Neurosci. (2011) 49:5-8. doi: 10.1002/0471141755.ph0508s49

15. Commons KG, Cholanians AB, Babb JA, Ehlinger DG. The rodent forced swim test measures stress-coping strategy, not depression-like behavior. ACS Chem Neurosci. (2017) 8:955-60. doi: 10.1021/acschemneuro.7b00042

16. Calhoon GG, Tye KM. Resolving the neural circuits of anxiety. Nat Neurosci. (2015) 18:1394-404. doi: 10.1038/nn.4101

17. Gururajan A, Reif A, Cryan JF, Slattery DA. The future of rodent models in depression research. Nat Rev Neurosci. (2019) 20:686701. doi: 10.1038/s41583-019-0221-6

18. Ramaker MJ, Dulawa SC. Identifying fast-onset antidepressants using rodent models. Mol Psychiatry. (2017) 22:656-65. doi: 10.1038/mp.2017.36

19. Albert PR, Vahid-Ansari F, Luckhart C. Serotonin-prefrontal cortical circuitry in anxiety and depression phenotypes: pivotal role of pre- and post-synaptic 5-HT1A receptor expression. Front Behav Neurosci. (2014) 8:199. doi: 10.3389/fnbeh.2014.00199

20. Muir J, Lopez J, Bagot RC. Wiring the depressed brain: optogenetic and chemogenetic circuit interrogation in animal models of depression. Neuropsychopharmacology. (2019) 44:101326. doi: 10.1038/s41386-018-0291-6

21. Hare BD, Duman RS. Prefrontal cortex circuits in depression and anxiety: contribution of discrete neuronal populations and target regions. $\mathrm{Mol}$ Psychiatry. (2020) 25:2742-58. doi: 10.1038/s41380-020-0685-9

22. Biselli T, Lange SS, Sablottny L, Steffen J, Walther A. Optogenetic and chemogenetic insights into the neurocircuitry of depression-like behaviour: 
a systematic review. Eur J Neurosci. (2021) 53:9-38. doi: 10.1111/ejn. 14603

23. Bittar TP, Labonte B. Functional contribution of the medial prefrontal circuitry in major depressive disorder and stressinduced depressive-like behaviors. Front Behav Neurosci. (2021) 15:699592. doi: 10.3389/fnbeh.2021.699592

24. Heninger GR, Delgado PL, Charney DS. The revised monoamine theory of depression: a modulatory role for monoamines, based on new findings from monoamine depletion experiments in humans. Pharmacopsychiatry. (1996) 29:2-11. doi: 10.1055/s-2007-979535

25. Blier P, De Montigny C. Possible serotonergic mechanisms underlying the antidepressant and anti- obsessive-compulsive disorder responses. Biol Psychiatry. (1998) 44:313-23. doi: 10.1016/S0006-3223(98)00114-0

26. Arango V, Underwood MD, Boldrini M, Tamir H, Kassir SA, Hsiung $S$, et al. Serotonin 1A receptors, serotonin transporter binding and serotonin transporter mRNA expression in the brainstem of depressed suicide victims. Neuropsychopharmacology. (2001) 25:892-903. doi: 10.1016/S0893-133X(01)00310-4

27. Cervo L, Canetta A, Calcagno E, Burbassi S, Sacchetti G, Caccia S, et al. Genotype-dependent activity of tryptophan hydroxylase-2 determines the response to citalopram in a mouse model of depression. J Neurosci. (2005) 25:8165-72. doi: 10.1523/JNEUROSCI.1816-05.2005

28. Zhang X, Gainetdinov RR, Beaulieu JM, Sotnikova TD, Burch LH, Williams RB, et al. Loss-of-function mutation in tryptophan hydroxylase2 identified in unipolar major depression. Neuron. (2005) 45:116. doi: 10.1016/j.neuron.2004.12.014

29. Richardson-Jones JW, Craige CP, Guiard BP, Stephen A, Metzger KL, Kung HF, et al. 5-HT(1A) autoreceptor levels determine vulnerability to stress and response to antidepressants. Neuron. (2010) 65:40-52. doi: 10.1016/j.neuron.2009.12.003

30. Jacobsen JP, Medvedev IO, Caron MG. The 5-HT deficiency theory of depression: perspectives from a naturalistic 5-HT deficiency model, the tryptophan hydroxylase 2Arg439His knockin mouse. Philos Trans $R$ Soc Lond B Biol Sci. (2012) 367:2444-59. doi: 10.1098/rstb.2012. 0109

31. Matthews PR, Harrison PJ. A morphometric, immunohistochemical, and in situ hybridization study of the dorsal raphe nucleus in major depression, bipolar disorder, schizophrenia, and suicide. J Affect Disord. (2012) 137:12534. doi: $10.1016 /$ j.jad.2011.10.043

32. Rajkowska G, Mahajan G, Legutko B, Challagundla L, Griswold M, Albert PR, et al. Length of axons expressing the serotonin transporter in orbitofrontal cortex is lower with age in depression. Neuroscience. (2017) 359:30-9. doi: 10.1016/j.neuroscience.2017.07.006

33. Riad M, Kobert A, Descarries L, Boye S, Rompre PP, Lacaille JC. Chronic fluoxetine rescues changes in plasma membrane density of 5-HT1A autoreceptors and serotonin transporters in the olfactory bulbectomy rodent model of depression. Neuroscience. (2017) 356:7888. doi: 10.1016/j.neuroscience.2017.05.021

34. Nazzi S, Maddaloni G, Pratelli M, Pasqualetti M. Fluoxetine induces morphological rearrangements of serotonergic fibers in the hippocampus. ACS Chem Neurosci. (2019) 10:321824. doi: 10.1021 /acschemneuro. 8 b00655

35. Pratelli M, Pasqualetti M. Serotonergic neurotransmission manipulation for the understanding of brain development and function: Learning from Tph2 genetic models. Biochimie. (2019) 161:3-14. doi: 10.1016/j.biochi.2018.11.016

36. Prakash N, Stark CJ, Keisler MN, Luo L, Der-Avakian A, Dulcis D. Serotonergic plasticity in the dorsal raphe nucleus characterizes susceptibility and resilience to anhedonia. J Neurosci. (2020) 40:56984. doi: 10.1523/JNEUROSCI.1802-19.2019

37. Harmer CJ. Serotonin and emotional processing: does it help explain antidepressant drug action? Neuropharmacology. (2008) 55:1023-8. doi: 10.1016/j.neuropharm.2008.06.036

38. Hirschfeld RM. History and evolution of the monoamine hypothesis of depression. J Clin Psychiatry. (2000) 61:4-6.

39. Cowen PJ. Serotonin and depression: pathophysiological mechanism or marketing myth? Trends Pharmacol Sci. (2008) 29:433-6. doi: 10.1016/j.tips.2008.05.004
40. Albert PR, Benkelfat C, Descarries L. The neurobiology of depression-revisiting the serotonin hypothesis. I Cellular and molecular mechanisms. Philos Trans R Soc Lond B Biol Sci. (2012) 367:2378-81. doi: 10.1098/rstb.2012.0190

41. Tork I. Anatomy of the serotonergic system. Ann N Y Acad Sci. (1990) 600:9-34 doi: 10.1111/j.1749-6632.1990.tb16870.x

42. Vertes RP. A PHA-L analysis of ascending projections of the dorsal raphe nucleus in the rat. J Comp Neurol. (1991) 313:643-68. doi: 10.1002/cne.903130409

43. Vertes RP, Fortin WJ, Crane AM. Projections of the median raphe nucleus in the rat. J Comp Neurol. (1999) 407:55582. doi: 10.1002/(SICI)1096-9861(19990517)407:4\&lt;555::AIDCNE7\&gt;3.0.CO;2-E

44. Walther DJ, Peter JU, Bashammakh S, Hortnagl H, Voits M, Fink H, et al. Synthesis of serotonin by a second tryptophan hydroxylase isoform. Science. (2003) 299:76. doi: 10.1126/science.1078197

45. Bach-Mizrachi H, Underwood MD, Kassir SA, Bakalian MJ, Sibille E, Tamir H, et al. Neuronal tryptophan hydroxylase mRNA expression in the human dorsal and median raphe nuclei: major depression and suicide. Neuropsychopharmacology. (2006) 31:814-24. doi: 10.1038/sj.npp.1300897

46. Lesch KP, Araragi N, Waider J, Van Den Hove D, Gutknecht L. Targeting brain serotonin synthesis: insights into neurodevelopmental disorders with long-term outcomes related to negative emotionality, aggression and antisocial behaviour. Philos Trans R Soc Lond B Biol Sci. (2012) 367:242643. doi: $10.1098 /$ rstb. 2012.0039

47. Anderson IM, Tomenson BM. The efficacy of selective serotonin re-uptake inhibitors in depression: a meta-analysis of studies against tricyclic antidepressants. J Psychopharmacol. (1994) 8:238-49. doi: 10.1177/026988119400800407

48. Stahl SM. Mechanism of action of serotonin selective reuptake inhibitors. Serotonin receptors and pathways mediate therapeutic effects and side effects. J Affect Disord. (1998) 51:215-35. doi: 10.1016/S0165-0327(98)00221-3

49. Andrade R, Haj-Dahmane S. Serotonin neuron diversity in the dorsal raphe. ACS Chem Neurosci. (2013) 4:22-5. doi: 10.1021/cn300224n

50. Commons KG. Dorsal raphe organization. J Chem Neuroanat. (2020) 110:101868. doi: 10.1016/j.jchemneu.2020.101868

51. Okaty BW, Sturrock N, Escobedo Lozoya Y, Chang Y, Senft RA, Lyon KA, et al. A single-cell transcriptomic and anatomic atlas of mouse dorsal raphe Pet1 neurons. Elife. (2020) 9:e55523. doi: 10.7554/eLife.55523

52. Calizo LH, Akanwa A, Ma X, Pan YZ, Lemos JC, Craige C, et al. Raphe serotonin neurons are not homogenous: electrophysiological, morphological and neurochemical evidence. Neuropharmacology. (2011) 61:524-43. doi: 10.1016/j.neuropharm.2011.04.008

53. Kiyasova V, Bonnavion P, Scotto-Lomassese S, Fabre V, Sahly I, Tronche F, et al. A subpopulation of serotonergic neurons that do not express the 5-HT1A autoreceptor. ACS Chem Neurosci. (2013) 4:89-95. doi: 10.1021/cn300157s

54. Amilhon B, Lepicard E, Renoir T, Mongeau R, Popa D, Poirel O, et al. VGLUT3 (vesicular glutamate transporter type 3) contribution to the regulation of serotonergic transmission and anxiety. J Neurosci. (2010) 30:2198-210. doi: 10.1523/JNEUROSCI.5196-09.2010

55. Commons KG. Ascending serotonin neuron diversity under two umbrellas. Brain Struct Funct. (2016) 221:3347-60. doi: 10.1007/s00429-015-1176-7

56. Ren J, Friedmann D, Xiong J, Liu CD, Ferguson BR, Weerakkody T, et al. Anatomically defined and functionally distinct dorsal raphe serotonin sub-systems. Cell. (2018) 175:472-87e420. doi: 10.1016/j.cell.2018.07.043

57. Bjorklund A, Lindvall O. Regeneration of normal terminal innervation patterns by central noradrenergic neurons after 5,7dihydroxytryptamine-induced axotomy in the adult rat. Brain Res. (1979) 171:271-93. doi: 10.1016/0006-8993(79)90333-0

58. Zhou FC, Azmitia EC. Induced homotypic sprouting of serotonergic fibers in hippocampus. II An immunocytochemistry study. Brain Res. (1986) 373:337-48. doi: 10.1016/0006-8993(86)90348-3

59. Blue ME, Molliver ME. 6-Hydroxydopamine induces serotonergic axon sprouting in cerebral cortex of newborn rat. Brain Res. (1987) 429:25569. doi: 10.1016/0165-3806(87)90106-4

60. Frankfurt M, Beaudet A. Reinnervation of dopamine neurons by regenerating serotonin axons in the rat medial zona incerta. A combined 
radioautographic and immunocytochemical ultrastructural study. Exp Brain Res. (1988) 72:473-80. doi: 10.1007/BF00250592

61. Descarries L, Soghomonian JJ, Garcia S, Doucet G, Bruno JP. Ultrastructural analysis of the serotonin hyperinnervation in adult rat neostriatum following neonatal dopamine denervation with 6-hydroxydopamine. Brain Res. (1992) 569:1-13. doi: 10.1016/0006-8993(92)90363-E

62. Jin Y, Dougherty SE, Wood K, Sun L, Cudmore RH, Abdalla A, et al. Regrowth of serotonin axons in the adult mouse brain following injury. Neuron. (2016) 91:748-62. doi: 10.1016/j.neuron.2016.07.024

63. Kajstura TJ, Dougherty SE, Linden DJ. Serotonin axons in the neocortex of the adult female mouse regrow after traumatic brain injury. J Neurosci Res. (2018) 96:512-26. doi: 10.1002/jnr.24059

64. Zahrai A, Vahid-Ansari F, Daigle M, Albert PR. Fluoxetineinduced recovery of serotonin and norepinephrine projections in a mouse model of post-stroke depression. Transl Psychiatry. (2020) 10:334. doi: 10.1038/s41398-020-01008-9

65. Liu Y, Nakamura S. Stress-induced plasticity of monoamine axons. Front Biosci. (2006) 11:1794-801. doi: 10.2741/1923

66. Veerakumar A, Challis C, Gupta P, Da J, Upadhyay A, Beck SG, et al. Antidepressant-like effects of cortical deep brain stimulation coincide with pro-neuroplastic adaptations of serotonin systems. Biol Psychiatry. (2014) 76:203-12. doi: 10.1016/j.biopsych.2013.12.009

67. Wihan J, Grosch J, Kalinichenko LS, Muller CP, Winkler J, Kohl Z. Layerspecific axonal degeneration of serotonergic fibers in the prefrontal cortex of aged A53T alpha-synuclein-expressing mice. Neurobiol Aging. (2019) 80:29-37. doi: 10.1016/j.neurobiolaging.2019.03.014

68. Gagnon D, Gregoire L, Di Paolo T, Parent M. Serotonin hyperinnervation of the striatum with high synaptic incidence in parkinsonian monkeys. Brain Struct Funct. (2016) 221:3675-91. doi: 10.1007/s00429-015-1125-5

69. Beaudet A, Descarries L. Quantitative data on serotonin nerve terminals in adult rat neocortex. Brain Res. (1976) 111:3019. doi: 10.1016/0006-8993(76)90775-7

70. Beaudet A, Descarries L. The fine structure of central serotonin neurons. $J$ Physiol (Paris). (1981) 77:193-203.

71. Steinbusch HW. Distribution of serotonin-immunoreactivity in the central nervous system of the rat-cell bodies and terminals. Neuroscience. (1981) 6:557-618. doi: 10.1016/0306-4522(81)90146-9

72. Barnes NM, Ahern GP, Becamel C, Bockaert J, Camilleri M, ChaumontDubel S, et al. International union of basic and clinical pharmacology. CX classification of receptors for 5-hydroxytryptamine; pharmacology and function. Pharmacol Rev. (2021) 73:310-520. doi: 10.1124/pr.118. 015552

73. Lidov HG, Molliver ME. An immunohistochemical study of serotonin neuron development in the rat: ascending pathways and terminal fields. Brain Res Bull. (1982) 8:389-430. doi: 10.1016/0361-9230(82) 90077-6

74. Kiyasova V, Gaspar P. Development of raphe serotonin neurons from specification to guidance. Eur J Neurosci. (2011) 34:1553-62. doi: 10.1111/j.1460-9568.2011.07910.x

75. Fitoussi A, Dellu-Hagedorn F, De Deurwaerdere P. Monoamines tissue content analysis reveals restricted and site-specific correlations in brain regions involved in cognition. Neuroscience. (2013) 255:233-45. doi: 10.1016/j.neuroscience.2013.09.059

76. Deneris E, Gaspar P. Serotonin neuron development: shaping molecular and structural identities. Wiley Interdiscip Rev Dev Biol. (2018) 7:e301. doi: 10.1002/wdev.301

77. Okaty BW, Commons KG, Dymecki SM. Embracing diversity in the 5-HT neuronal system. Nat Rev Neurosci. (2019) 20:397-424. doi: 10.1038/s41583-019-0151-3

78. Donovan LJ, Spencer WC, Kitt MM, Eastman BA, Lobur KJ, Jiao K, et al. Lmx1b is required at multiple stages to build expansive serotonergic axon architectures. Elife. (2019) 8:e48788. doi: 10.7554/eLife.48788

79. Donovan SL, Mamounas LA, Andrews AM, Blue ME, Mccasland JS. GAP-43 is critical for normal development of the serotonergic innervation in forebrain. $J$ Neurosci. (2002) 22:3543-52. doi: 10.1523/JNEUROSCI.22-09-03543.2002

80. Fournet V, Jany M, Fabre V, Chali F, Orsal D, Schweitzer A, et al. The deletion of the microtubule-associated STOP protein affects the serotonergic mouse brain network. J Neurochem. (2010) 115:157994. doi: 10.1111/j.1471-4159.2010.07064.x

81. Fournet V, Schweitzer A, Chevarin C, Deloulme JC, Hamon M, Giros B, et al. The deletion of STOP/MAP6 protein in mice triggers highly altered mood and impaired cognitive performances. J Neurochem. (2012) 121:99114. doi: 10.1111/j.1471-4159.2011.07615.x

82. Fenstermaker AG, Prasad AA, Bechara A, Adolfs Y, Tissir F, Goffinet A, et al. Wnt/planar cell polarity signaling controls the anterior-posterior organization of monoaminergic axons in the brainstem. J Neurosci. (2010) 30:16053-64. doi: 10.1523/JNEUROSCI.4508-10.2010

83. Bagri A, Marin O, Plump AS, Mak J, Pleasure SJ, Rubenstein JL, et al. Slit proteins prevent midline crossing and determine the dorsoventral position of major axonal pathways in the mammalian forebrain. Neuron. (2002) 33:233-48. doi: 10.1016/S0896-6273(02)00561-5

84. Lopez-Bendito G, Flames N, Ma L, Fouquet C, Di Meglio T, Chedotal A, et al. Robo1 and Robo2 cooperate to control the guidance of major axonal tracts in the mammalian forebrain. J Neurosci. (2007) 27:3395407. doi: 10.1523/JNEUROSCI.4605-06.2007

85. Katori S, Hamada S, Noguchi Y, Fukuda E, Yamamoto T, Yamamoto H, et al. Protocadherin-alpha family is required for serotonergic projections to appropriately innervate target brain areas. J Neurosci. (2009) 29:913747. doi: 10.1523/JNEUROSCI.5478-08.2009

86. Flaherty E, Maniatis T. The role of clustered protocadherins in neurodevelopment and neuropsychiatric diseases. Curr Opin Genet Dev. (2020) 65:144-50. doi: 10.1016/j.gde.2020.05.041

87. Chen WV, Nwakeze CL, Denny CA, O’Keeffe S, Rieger MA, Mountoufaris G, et al. Pcdhalphac2 is required for axonal tiling and assembly of serotonergic circuitries in mice. Science. (2017) 356:406-11. doi: 10.1126/science.aal3231

88. Vadodaria KC, Ji Y, Skime M, Paquola AC, Nelson T, Hall-Flavin $\mathrm{D}$, et al. Altered serotonergic circuitry in SSRI-resistant major depressive disorder patient-derived neurons. Mol Psychiatry. (2019) 24:808-18. doi: 10.1038/s41380-019-0377-5

89. Roberson-Nay R, Lapato DM, Wolen AR, Lancaster EE, Webb BT, Verhulst B, et al. An epigenome-wide association study of earlyonset major depression in monozygotic twins. Transl Psychiatry. (2020) 10:301. doi: 10.1038/s41398-020-00984-2

90. Dahlström A, Fuxe K. Evidence for the existence of monoamine-containing neurons in the central nervous system. I demonstration of monoamines in the cell bodies of brain stem neurons. Acta Physiol Scand Suppl. (1964) 232:231-55.

91. Descarries L, Riad M, Parent M. Ultrastructure of the serotonin innervation in the mammalian central nervous system. Handb Behav Neurosci. (2010) 21:65-101. doi: 10.1016/S1569-7339(10)70072-2

92. Nielsen K, Brask D, Knudsen GM, Aznar S. Immunodetection of the serotonin transporter protein is a more valid marker for serotonergic fibers than serotonin. Synapse. (2006) 59:270-6. doi: 10.1002/syn.20240

93. Brown P, Molliver ME. Dual serotonin (5-HT) projections to the nucleus accumbens core and shell: relation of the 5-HT transporter to amphetamine-induced neurotoxicity. J Neurosci. (2000) 20:195263. doi: 10.1523/JNEUROSCI.20-05-01952.2000

94. Janušonis S. Serotonin dynamics in and around the central nervous system: is autism solvable without fundamental insights? Int J Dev Neurosci. (2014) 39:9-15. doi: 10.1016/j.ijdevneu.2014.05.009

95. Janušonis S. Serotonin in space: understanding single fibers. ACS Chem Neurosci. (2017) 8:893-6. doi: 10.1021/acschemneuro.6b00417

96. Lebrand C, Cases O, Adelbrecht C, Doye A, Alvarez C, El Mestikawy $\mathrm{S}$, et al. Transient uptake and storage of serotonin in developing thalamic neurons. Neuron. (1996) 17:823-35. doi: 10.1016/S0896-6273(00) 80215-9

97. Narboux-Neme N, Pavone LM, Avallone L, Zhuang X, Gaspar P. Serotonin transporter transgenic (SERTcre) mouse line reveals developmental targets of serotonin specific reuptake inhibitors (SSRIs). Neuropharmacology. (2008) 55:994-1005. doi: 10.1016/j.neuropharm.2008.08.020

98. Sulzer D, Edwards RH. Antidepressants and the monoamine masquerade. Neuron. (2005) 46:1-2. doi: 10.1016/j.neuron.2005.03.013

99. Zhou FM, Liang Y, Salas R, Zhang L, De Biasi M, Dani JA. Corelease of dopamine and serotonin from striatal dopamine terminals. Neuron. (2005) 46:65-74. doi: 10.1016/j.neuron.2005.02.010 
100. Gantz SC, Levitt ES, Llamosas N, Neve KA, Williams JT. Depression of serotonin synaptic transmission by the dopamine precursor L-DOPA. Cell Rep. (2015) 12:944-54. doi: 10.1016/j.celrep.2015.07.005

101. Beaudet A, Descarries L. The monoamine innervation of rat cerebral cortex: synaptic and nonsynaptic axon terminals. Neuroscience. (1978) 3:85160. doi: 10.1016/0306-4522(78)90115-X

102. Fuxe K, Dahlström A, Höistad M, Marcellino D, Jansson A, Rivera A, et al. From the Golgi-Cajal mapping to the transmitter-based characterization of the neuronal networks leading to two modes of brain communication: wiring and volume transmission. Brain Res Rev. (2007) 55:17-54. doi: 10.1016/j.brainresrev.2007.02.009

103. Fuxe K, Dahlstrom AB, Jonsson G, Marcellino D, Guescini M, Dam $M$, et al. The discovery of central monoamine neurons gave volume transmission to the wired brain. Prog Neurobiol. (2010) 90:82-100. doi: 10.1016/j.pneurobio.2009.10.012

104. Bang SJ, Jensen P, Dymecki SM, Commons KG. Projections and interconnections of genetically defined serotonin neurons in mice. Eur $J$ Neurosci. (2012) 35:85-96. doi: 10.1111/j.1460-9568.2011.07936.x

105. Hainer C, Mosienko V, Koutsikou S, Crook JJ, Gloss B, Kasparov $\mathrm{S}$, et al. Beyond gene inactivation: evolution of tools for analysis of serotonergic circuitry. ACS Chem Neurosci. (2015) 6:1116-29. doi: 10.1021/acschemneuro.5b00045

106. Luo L, Callaway EM, Svoboda K. Genetic dissection of neural circuits: a decade of progress. Neuron. (2018) 98:25681. doi: 10.1016/j.neuron.2018.03.040

107. Pollak Dorocic I, Furth D, Xuan Y, Johansson Y, Pozzi L, Silberberg G, et al. A whole-brain atlas of inputs to serotonergic neurons of the dorsal and median raphe nuclei. Neuron. (2014) 83:663-78. doi: 10.1016/j.neuron.2014.07.002

108. Weissbourd B, Ren J, Deloach KE, Guenthner CJ, Miyamichi K, Luo L. Presynaptic partners of dorsal raphe serotonergic and GABAergic neurons. Neuron. (2014) 83:645-62. doi: 10.1016/j.neuron.2014.06.024

109. Fernandez SP, Cauli B, Cabezas C, Muzerelle A, Poncer JC, Gaspar P. Multiscale single-cell analysis reveals unique phenotypes of raphe 5-HT neurons projecting to the forebrain. Brain Struct Funct. (2016) 221:400725. doi: 10.1007/s00429-015-1142-4

110. Muzerelle A, Scotto-Lomassese S, Bernard JF, Soiza-Reilly M, Gaspar P. Conditional anterograde tracing reveals distinct targeting of individual serotonin cell groups (B5-B9) to the forebrain and brainstem. Brain Struct Funct. (2016) 221:535-61. doi: 10.1007/s00429-014-0924-4

111. Zhou L, Liu MZ, Li Q, Deng J, Mu D, Sun YG. Organization of functional long-range circuits controlling the activity of serotonergic neurons in the dorsal raphe nucleus. Cell Rep. (2017) 18:3018-32. doi: 10.1016/j.celrep.2017.02.077

112. Van Bockstaele EJ, Biswas A, Pickel VM. Topography of serotonin neurons in the dorsal raphe nucleus that send axon collaterals to the rat prefrontal cortex and nucleus accumbens. Brain Res. (1993) 624:18898. doi: 10.1016/0006-8993(93)90077-Z

113. Gagnon D, Parent M. Distribution of VGLUT3 in highly collateralized axons from the rat dorsal raphe nucleus as revealed by single-neuron reconstructions. PLoS One. (2014) 9:e87709. doi: 10.1371/journal.pone.0087709

114. Belmer A, Patkar OL, Pitman KM, Bartlett SE. Serotonergic Neuroplasticity in Alcohol Addiction. Brain Plast. (2016) 1:177-206. doi: 10.3233/BPL-150022

115. Belmer A, Klenowski PM, Patkar OL, Bartlett SE. Mapping the connectivity of serotonin transporter immunoreactive axons to excitatory and inhibitory neurochemical synapses in the mouse limbic brain. Brain Struct Funct. (2017) 222:1297-314. doi: 10.1007/s00429-016-1278-x

116. Baker KG, Halliday GM, Halasz P, Hornung JP, Geffen LB, Cotton RG, et al. Cytoarchitecture of serotonin-synthesizing neurons in the pontine tegmentum of the human brain. Synapse. (1991) 7:301-20. doi: 10.1002/syn.890070407

117. Hornung JP. The human raphe nuclei and the serotonergic system. J Chem Neuroanat. (2003) 26:331-43. doi: 10.1016/j.jchemneu.2003.10.002

118. Azmitia EC, Singh JS, Whitaker-Azmitia PM. Increased serotonin axons (immunoreactive to 5-HT transporter) in postmortem brains from young autism donors. Neuropharmacology. (2011) 60:1347-54. doi: 10.1016/j.neuropharm.2011.02.002
119. Ishikawa J, Ishikawa A, Nakamura S. Interferon-alpha reduces the density of monoaminergic axons in the rat brain. Neuroreport. (2007) 18:13740. doi: 10.1097/WNR.0b013e328010231a

120. Agnati LF, Fuxe K, Zoli M, Ozini I, Toffano G, Ferraguti F. A correlation analysis of the regional distribution of central enkephalin and beta-endorphin immunoreactive terminals and of opiate receptors in adult and old male rats. Evidence for the existence of two main types of communication in the central nervous system: the volume transmission and the wiring transmission. Acta Physiol Scand. (1986) 128:201-7. doi: 10.1111/j.1748-1716.1986.tb07967.x

121. Jennings KA. A comparison of the subsecond dynamics of neurotransmission of dopamine and serotonin. ACS Chem Neurosci. (2013) 4:704-14. doi: 10.1021/cn4000605

122. Bjelke B, Strömberg I, O'Connor WT, Andbjer B, Agnati LF, Fuxe K. Evidence for volume transmission in the dopamine denervated neostriatum of the rat after a unilateral nigral 6-OHDA microinjection. Studies with systemic D-amphetamine treatment. Brain Res. (1994) 662:1124. doi: 10.1016/0006-8993(94)90791-9

123. Bjelke B, England R, Nicholson C, Rice ME, Lindberg J, Zoli M, et al. Long distance pathways of diffusion for dextran along fibre bundles in brain. Relevance for volume transmission. Neuroreport. (1995) 6:10059. doi: 10.1097/00001756-199505090-00014

124. Sulzer D, Cragg SJ, Rice ME. Striatal dopamine neurotransmission: regulation of release and uptake. Basal Ganglia. (2016) 6:12348. doi: 10.1016/j.baga.2016.02.001

125. Post MR, Sulzer D. The chemical tools for imaging dopamine release. Cell Chem Biol. (2021) 28:748-64. doi: 10.1016/j.chembiol.2021.04.005

126. Vizi ES, Fekete A, Karoly R, Mike A. Non-synaptic receptors and transporters involved in brain functions and targets of drug treatment. $\mathrm{Br} J$ Pharmacol. (2010) 160:785-809. doi: 10.1111/j.1476-5381.2009.00624.x

127. Borroto-Escuela DO, Perez De La Mora M, Manger P, Narvaez M, Beggiato $\mathrm{S}$, Crespo-Ramirez M, et al. Brain dopamine transmission in health and parkinson's disease: modulation of synaptic transmission and plasticity through volume transmission and dopamine heteroreceptors. Front Synaptic Neurosci. (2018) 10:20. doi: 10.3389/fnsyn.2018.00020

128. Martin A, Szczupak B, Gomez-Vallejo V, Plaza S, Padro D, Cano A, et al. PET imaging of serotoninergic neurotransmission with [(11)C]DASB and [(18)F]altanserin after focal cerebral ischemia in rats. J Cereb Blood Flow Metab. (2013) 33:1967-75. doi: 10.1038/jcbfm.2013.156

129. Martin KA, Spuhler IA. The fine structure of the dopaminergic innervation of area 10 of macaque prefrontal cortex. Eur J Neurosci. (2013) 37:106171. doi: $10.1111 /$ ejn. 12124

130. Rice ME, Cragg SJ. Dopamine spillover after quantal release: rethinking dopamine transmission in the nigrostriatal pathway. Brain Res Rev. (2008) 58:303-13. doi: 10.1016/j.brainresrev.2008.02.004

131. Fuxe K, Ungerstedt U. Histochemical, biochemical and functional studies on central monoamine neurons after acute and chronic amphetamine administration. In: Costa E, Garattini S, editors. Amphetamines and Related Compounds. New York, NY: Raven Press (1970). p. 257-288.

132. Fuxe K, Hokfelt T, Jonsson G, Ungerstedt U. Fluorescence microscopy in neuroanatomy. In: Nauta WJH, Ebbesson SOE, editors. Contemporary Research Methods in Neuroanatomy. Berlin: Springer-Verlag (1970). p. 275314.

133. Descarries L, Watkins KC, Garcia S, Beaudet A. The serotonin neurons in nucleus raphe dorsalis of adult rat: a light and electron microscope radioautographic study. J Comp Neurol. (1982) 207:239-54. doi: 10.1002/cne.902070305

134. Bunin MA, Wightman RM. Quantitative evaluation of 5hydroxytryptamine (serotonin) neuronal release and uptake: an investigation of extrasynaptic transmission. J Neurosci. (1998) 18:4854-60. doi: 10.1523/JNEUROSCI.18-13-04854.1998

135. Bunin MA, Wightman RM. Paracrine neurotransmission in the CNS: involvement of 5-HT. Trends Neurosci. (1999) 22:377-82. doi: 10.1016/S0166-2236(99)01410-1

136. Colgan LA, Cavolo SL, Commons KG, Levitan ES. Action potential-independent and pharmacologically unique vesicular serotonin release from dendrites. J Neurosci. (2012) 32:1573746. doi: 10.1523/JNEUROSCI.0020-12.2012 
137. Quentin E, Belmer A, Maroteaux L. Somato-dendritic regulation of raphe serotonin neurons; a key to antidepressant action. Front Neurosci. (2018) 12:982. doi: 10.3389/fnins.2018.00982

138. Vahid-Ansari F, Daigle M, Manzini MC, Tanaka KF, Hen R, Geddes $\mathrm{SD}$, et al. Abrogated Freud-1/Cc2d1a repression of 5-HT1A autoreceptors induces fluoxetine-resistant anxiety/depression-like behavior. J Neurosci. (2017) 37:11967-78. doi: 10.1523/JNEUROSCI.1668-17.2017

139. Belmer A, Quentin E, Diaz SL, Guiard BP, Fernandez SP, Doly S, et al. Positive regulation of raphe serotonin neurons by serotonin 2B receptors. Neuropsychopharmacology. (2018) 43:1623-32. doi: 10.1038/s41386-018-0013-0

140. Andrade R, Huereca D, Lyons JG, Andrade EM, Mcgregor KM. 5-HT1A receptor-mediated autoinhibition and the control of serotonergic cell firing. ACS Chem Neurosci. (2015) 6:1110-5. doi: 10.1021/acschemneuro.5b00034

141. Hikima T, Lee CR, Witkovsky $P$, Chesler J, Ichtchenko K, Rice ME. Activity-dependent somatodendritic dopamine release in the substantia nigra autoinhibits the releasing neuron. Cell Rep. (2021) 35:108951. doi: 10.1016/j.celrep.2021.108951

142. Wallace JA, Lauder JM. Development of the serotonergic system in the rat embryo: an immunocytochemical study. Brain Res Bull. (1983) 10:45979. doi: 10.1016/0361-9230(83)90144-2

143. Aitken AR, Tork I. Early development of serotonin-containing neurons and pathways as seen in wholemount preparations of the fetal rat brain. J Comp Neurol. (1988) 274:32-47. doi: 10.1002/cne.902740105

144. Dinopoulos A, Dori I, Parnavelas JG. The serotonin innervation of the basal forebrain shows a transient phase during development. Brain Res Dev Brain Res. (1997) 99:38-52. doi: 10.1016/S0165-3806(96)00198-8

145. García-González D, Khodosevich K, Watanabe Y, Rollenhagen A, Lübke JH, Monyer H. Serotonergic projections govern postnatal neuroblast migration. Neuron. (2017) 94:534-549e539. doi: 10.1016/j.neuron.2017.04.013

146. Sargin D, Jeoung HS, Goodfellow NM, Lambe EK. Serotonin regulation of the prefrontal cortex: cognitive relevance and the impact of developmental perturbation. ACS Chem Neurosci. (2019) 10:3078-93. doi: 10.1021/acschemneuro.9b00073

147. Narboux-Neme N, Angenard G, Mosienko V, Klempin F, Pitychoutis PM, Deneris E, et al. Postnatal growth defects in mice with constitutive depletion of central serotonin. ACS Chem Neurosci. (2013) 4:17181. doi: $10.1021 / \mathrm{cn} 300165 \mathrm{x}$

148. Maddaloni G, Bertero A, Pratelli M, Barsotti N, Boonstra A, Giorgi A, et al. Development of serotonergic fibers in the post-natal mouse brain. Front Cell Neurosci. (2017) 11:202. doi: 10.3389/fncel.2017.00202

149. Pratelli M, Migliarini S, Pelosi B, Napolitano F, Usiello A, Pasqualetti M. Perturbation of serotonin homeostasis during adulthood affects serotonergic neuronal circuitry. eNeuro. (2017) 4:ENEURO.0376-16.2017. doi: 10.1523/ENEURO.0376-16.2017

150. Teissier A, Soiza-Reilly M, Gaspar P. Refining the role of 5-HT in postnatal development of brain circuits. Front Cell Neurosci. (2017) 11:139. doi: 10.3389/fncel.2017.00139

151. Chen X, Ye R, Gargus JJ, Blakely RD, Dobrenis K, Sze JY. Disruption of transient serotonin accumulation by non-serotonin-producing neurons impairs cortical map development. Cell Rep. (2015) 10:346-58. doi: 10.1016/j.celrep.2014.12.033

152. Yan W, Wilson CC, Haring JH. Effects of neonatal serotonin depletion on the development of rat dentate granule cells. Brain Res Dev Brain Res. (1997) 98:177-84. doi: 10.1016/S0165-3806(96)00176-9

153. Vitalis $T$, Cases $O$, Gillies $K$, Hanoun N, Hamon M, Seif I, et al. Interactions between $\operatorname{TrkB}$ signaling and serotonin excess in the developing murine somatosensory cortex: a role in tangential and radial organization of thalamocortical axons. J Neurosci. (2002) 22:49875000. doi: 10.1523/JNEUROSCI.22-12-04987.2002

154. Riccio O, Jacobshagen M, Golding B, Vutskits L, Jabaudon D, Hornung JP, et al. Excess of serotonin affects neocortical pyramidal neuron migration. Transl Psychiatry. (2011) 1:e47. doi: 10.1038/tp.2011.49

155. Toda T, Homma D, Tokuoka H, Hayakawa I, Sugimoto Y, Ichinose H, et al. Birth regulates the initiation of sensory map formation through serotonin signaling. Dev Cell. (2013) 27:32-46. doi: 10.1016/j.devcel.2013. 09.002
156. Vicenzi S, Foa L, Gasperini RJ. Serotonin functions as a bidirectional guidance molecule regulating growth cone motility. Cell Mol Life Sci. (2021) 78:2247-62. doi: 10.1007/s00018-020-03628-2

157. Hannon J, Hoyer D. Molecular biology of 5-HT receptors. Behav Brain Res. (2008) 195:198-213. doi: 10.1016/j.bbr.2008.03.020

158. Daval G, Verge D, Becerril A, Gozlan H, Spampinato U, Hamon M. Transient expression of 5-HT1A receptor binding sites in some areas of the rat CNS during postnatal development. Int J Dev Neurosci. (1987) 5:171-80. doi: 10.1016/0736-5748(87)90027-X

159. Del Olmo E, Diaz A, Guirao-Pineyro M, Del Arco C, Pascual J, Pazos A. Transient localization of 5-HT1A receptors in human cerebellum during development. Neurosci Lett. (1994) 166:149-52. doi: 10.1016/0304-3940(94)90472-3

160. Miquel MC, Kia HK, Boni C, Doucet E, Daval G, Matthiessen L, et al. Postnatal development and localization of 5-HT1A receptor mRNA in rat forebrain and cerebellum. Brain Res Develop Brain Res. (1994) 80:14957. doi: 10.1016/0165-3806(94)90099-X

161. Del Olmo E, Lopez-Gimenez JF, Vilaro MT, Mengod G, Palacios JM, Pazos A. Early localization of mRNA coding for 5-HT1A receptors in human brain during development. Brain Res Mol Brain Res. (1998) 60:1236. doi: 10.1016/S0169-328X(98)00149-1

162. Hamon M, Gozlan H, Mestikawy S, Emerit MB, Bolaños F, Schechter L. The central 5-HT1A receptors: pharmacological, biochemical, functional, and regulatory properties. Ann N Y Acad Sci. (1990) 600:114-29. doi: 10.1111/j.1749-6632.1990.tb16877

163. Hoyer D, Schoeffter P, Waeber C, Palacios JM. Serotonin 5-HT1D receptors. Ann N Y Acad Sci. (1990) 600:168-181.

164. Burnet PW, Eastwood SL, Lacey K, Harrison PJ. The distribution of 5HT1A and 5-HT2A receptor mRNA in human brain. Brain Res. (1995) 676:157-168.

165. Sotelo C, Cholley B, Mestikawy S, Gozlan H, Hamon M. 1990. Direct immunohistochemical evidence of the existence of 5-HT1A autoreceptors on serotoninergic neurons in the midbrain raphe nuclei. Eur J Neurosci. (1990) 2:1144-54. doi: 10.1111/j.1460-9568.1990.tb00026.x

166. Pompeiano M, Palacios JM, Mengod G. Distribution and cellular localization of mRNA coding for 5-HT1A receptor in the rat brain: correlation with receptor binding. J Neurosci. (1992) 12:440-53. doi: 10.1523/JNEUROSCI.12-02-00440.1992

167. Hall H, Lundkvist C, Halldin C, Farde L, Pike VW, Mccarron JA, et al. Autoradiographic localization of 5-HT1A receptors in the post-mortem human brain using [3H]WAY-100635 and [11C]way-100635. Brain Res. (1997) 745:96-108. doi: 10.1016/S0006-8993(96)01131-6

168. Mengod G, Palacios JM, Cortes R. Cartography of 5-HT1A and 5-HT2A receptor subtypes in prefrontal cortex and its projections. ACS Chem Neurosci. (2015) 6:1089-98. doi: 10.1021/acschemneuro.5b00023

169. Azmitia EC, Gannon PJ, Kheck NM, Whitaker-Azmitia PM. Cellular localization of the 5-HT1A receptor in primate brain neurons and glial cells. Neuropsychopharmacology. (1996) 14:35-46. doi: 10.1016/S0893-133X(96)80057-1

170. Merzak A, Koochekpour S, Fillion MP, Fillion G, Pilkington GJ. Expression of serotonin receptors in human fetal astrocytes and glioma cell lines: a possible role in glioma cell proliferation and migration. Brain Res Mol Brain Res. (1996) 41:1-7. doi: 10.1016/0169-328X(96)00058-7

171. Kikuoka R, Miyazaki I, Kubota N, Maeda M, Kagawa D, Moriyama M, et al. Mirtazapine exerts astrocyte-mediated dopaminergic neuroprotection. Sci Rep. (2020) 10:20698. doi: 10.1038/s41598-020-77652-4

172. Azmitia EC, Rubinstein VJ, Strafaci JA, Rios JC, Whitaker-Azmitia PM. 5-HT1A agonist and dexamethasone reversal of para-chloroamphetamine induced loss of MAP-2 and synaptophysin immunoreactivity in adult rat brain. Brain Res. (1995) 677:181-92. doi: 10.1016/0006-8993(95)00051-Q

173. Sikich L, Hickok JM, Todd RD. 5-HT1A receptors control neurite branching during development. Brain Res Dev Brain Res. (1990) 56:26974. doi: 10.1016/0165-3806(90)90092-D

174. Rojas PS, Neira D, Munoz M, Lavandero S, Fiedler JL. Serotonin (5HT) regulates neurite outgrowth through 5-HT1A and 5-HT7 receptors in cultured hippocampal neurons. J Neurosci Res. (2014) 92:10009. doi: 10.1002/jnr.23390 
175. Rumajogee P, Verge D, Hanoun N, Brisorgueil MJ, Hen R, Lesch KP, et al. Adaptation of the serotoninergic neuronal phenotype in the absence of 5-HT autoreceptors or the 5-HT transporter: involvement of BDNF and CAMP. Eur J Neurosci. (2004) 19:937-44. doi: 10.1111/j.0953-816X.2004.03194.x

176. Dudok JJ, Groffen AJ, Witter MP, Voorn P, Verhage M. Chronic activation of the 5-HT(2) receptor reduces 5-HT neurite density as studied in organotypic slice cultures. Brain Res. (2009) 1302:1-9. doi: 10.1016/j.brainres.2009. 08.071

177. Rojas PS, Fiedler JL. What do we really know about 5-HT1A receptor signaling in neuronal cells? Front Cell Neurosci. (2016) 10:272. doi: 10.3389/fncel.2016.00272

178. Albert PR, Vahid-Ansari F. The 5-HT1A receptor: signaling to behavior. Biochimie. (2019) 161:34-45. doi: 10.1016/j.biochi.2018.10.015

179. Kushwaha N, Albert PR. Coupling of 5-HT1A autoreceptors to inhibition of mitogen-activated protein kinase activation via Gbetagamma subunit signaling. Eur $J$ Neurosci. (2005) 21:721-32. doi: 10.1111/j.1460-9568.2005.03904.x

180. Mogha A, Guariglia SR, Debata PR, Wen GY, Banerjee P. Serotonin 1A receptor-mediated signaling through ERK and PKCalpha is essential for normal synaptogenesis in neonatal mouse hippocampus. Transl Psychiatry. (2012) 2:e66. doi: 10.1038/tp.2011.58

181. Albert PR, Sajedi N, Lemonde S, Ghahremani MH. Constitutive G(i2)dependent activation of adenylyl cyclase type II by the 5-HT1A receptor. Inhibition by anxiolytic partial agonists. J Biol Chem. (1999) 274:3546974. doi: $10.1074 / \mathrm{jbc}$.274.50.35469

182. Mehta M, Ahmed Z, Fernando SS, Cano-Sanchez P, Adayev T, Ziemnicka D, et al. Plasticity of 5-HT 1A receptor-mediated signaling during early postnatal brain development. J Neurochem. (2007) 101:918-28. doi: 10.1111/j.1471-4159.2007.04448.x

183. Yuen EY, Jiang Q, Chen P, Gu Z, Feng J, Yan Z. Serotonin 5HT1A receptors regulate NMDA receptor channels through a microtubule-dependent mechanism. J Neurosci. (2005) 25:5488501. doi: 10.1523/JNEUROSCI.1187-05.2005

184. Rojas PS, Aguayo F, Neira D, Tejos M, Aliaga E, Munoz JP, et al. Dual effect of serotonin on the dendritic growth of cultured hippocampal neurons: Involvement of 5-HT1A and 5-HT7 receptors. Mol Cell Neurosci. (2017) 85:148-61. doi: 10.1016/j.mcn.2017.09.009

185. Gaspar P, Cases O, Maroteaux L. The developmental role of serotonin: news from mouse molecular genetics. Nat Rev Neurosci. (2003) 4:100212. doi: $10.1038 / \mathrm{nrn} 1256$

186. Lesch KP, Waider J. Serotonin in the modulation of neural plasticity and networks: implications for neurodevelopmental disorders. Neuron. (2012) 76:175-91. doi: 10.1016/j.neuron.2012.09.013

187. Bonnin A, Torii M, Wang L, Rakic P, Levitt P. Serotonin modulates the response of embryonic thalamocortical axons to netrin-1. Nat Neurosci. (2007) 10:588-97. doi: 10.1038/nn1896

188. Vetencourt JF, Sale A, Viegi A, Baroncelli L, De Pasquale R, O'Leary OF, et al. The antidepressant fluoxetine restores plasticity in the adult visual cortex. Science. (2008) 320:385-8. doi: 10.1126/science.1150516

189. Maya Vetencourt JF, Tiraboschi E, Spolidoro M, Castren E, Maffei L. Serotonin triggers a transient epigenetic mechanism that reinstates adult visual cortex plasticity in rats. Eur J Neurosci. (2011) 33:4957. doi: 10.1111/j.1460-9568.2010.07488.x

190. Albert PR. Adult neuroplasticity: a new "cure" for major depression? J Psychiatry Neurosci. (2019) 44:147-50. doi: 10.1503/jpn.190072

191. Castren E, Monteggia LM. Brain-derived neurotrophic factor signaling in depression and antidepressant action. Biol Psychiatry. (2021) 90:12836. doi: 10.1016/j.biopsych.2021.05.008

192. Leysen JE. 5-HT2 receptors. Curr Drug Targets CNS Neurol Disord. (2004) 3:11-26. doi: 10.2174/1568007043482598

193. Pompeiano M, Palacios JM, Mengod G. Distribution of the serotonin 5-HT2 receptor family mRNAs: comparison between 5HT2A and 5-HT2C receptors. Brain Res Mol Brain Res. (1994) 23:163-78. doi: 10.1016/0169-328X(94)90223-2

194. Persico AM, Di Pino G, Levitt P. Multiple receptors mediate the trophic effects of serotonin on ventroposterior thalamic neurons in vitro. Brain Res. (2006) 1095:17-25. doi: 10.1016/j.brainres.2006.04.006
195. Dooley AE, Pappas IS, Parnavelas JG. Serotonin promotes the survival of cortical glutamatergic neurons in vitro. Exp Neurol. (1997) 148:20514. doi: 10.1006/exnr.1997.6633

196. Chameau P, Van Hooft JA. Serotonin 5-HT(3) receptors in the central nervous system. Cell Tissue Res. (2006) 326:57381. doi: 10.1007/s00441-006-0255-8

197. Engel M, Smidt MP, Van Hooft JA. The serotonin 5-HT3 receptor: a novel neurodevelopmental target. Front Cell Neurosci. (2013) 7:76. doi: 10.3389/fncel.2013.00076

198. Lotto B, Upton L, Price DJ, Gaspar P. Serotonin receptor activation enhances neurite outgrowth of thalamic neurones in rodents. Neurosci Lett. (1999) 269:87-90. doi: 10.1016/S0304-3940(99)00422-X

199. Sun H, Hu XQ, Emerit MB, Schoenebeck JC, Kimmel CE, Peoples RW, et al. Modulation of 5-HT3 receptor desensitization by the light chain of microtubule-associated protein 1B expressed in HEK 293 cells. J Physiol. (2008) 586:751-62. doi: 10.1113/jphysiol.2007.136440

200. Yu Y, Cao DQ, Xu HY, Sun M, Huang ZL, Yung WH, et al. 5-HT3A receptors are required in long-term depression and AMPA receptor internalization. Neuroscience. (2014) 278:105-12. doi: 10.1016/j.neuroscience.2014.07.070

201. Waeber C, Sebben M, Nieoullon A, Bockaert J, Dumuis A. Regional distribution and ontogeny of 5-HT4 binding sites in rodent brain. Neuropharmacology. (1994) 33:527-41. doi: 10.1016/0028-3908(94)90084-1

202. Vilaro MT, Cortes R, Gerald C, Branchek TA, Palacios JM, Mengod G. Localization of 5-HT4 receptor mRNA in rat brain by in situ hybridization histochemistry. Brain Res Mol Brain Res. (1996) 43:35660. doi: 10.1016/S0169-328X(96)00248-3

203. Bonaventure P, Hall H, Gommeren W, Cras P, Langlois X, Jurzak M, et al. Mapping of serotonin 5-HT(4) receptor mRNA and ligand binding sites in the post-mortem human brain. Synapse. (2000) 36:35-46. doi: 10.1002/(SICI)1098-2396(200004)36:1\&lt;35::AIDSYN4\&gt;3.0.CO;2-Y

204. Pindon A, Van Hecke G, Van Gompel P, Lesage AS, Leysen JE, Jurzak M. Differences in signal transduction of two 5-HT4 receptor splice variants: compound specificity and dual coupling with Galphas- and Galphai/oproteins. Mol Pharmacol. (2002) 61:85-96. doi: 10.1124/mol.61.1.85

205. Barthet G, Framery B, Gaven F, Pellissier L, Reiter E, Claeysen S, et al. 5-hydroxytryptamine 4 receptor activation of the extracellular signal-regulated kinase pathway depends on Src activation but not on G protein or beta-arrestin signaling. Mol Biol Cell. (2007) 18:197991. doi: 10.1091/mbc.e06-12-1080

206. Kvachnina E, Liu G, Dityatev A, Renner U, Dumuis A, Richter DW, et al. 5HT7 receptor is coupled to G alpha subunits of heterotrimeric G12-protein to regulate gene transcription and neuronal morphology. J Neurosci. (2005) 25:7821-30. doi: 10.1523/JNEUROSCI.1790-05.2005

207. Restivo L, Roman F, Dumuis A, Bockaert J, Marchetti E, AmmassariTeule M. The promnesic effect of G-protein-coupled 5-HT4 receptors activation is mediated by a potentiation of learning-induced spine growth in the mouse hippocampus. Neuropsychopharmacology. (2008) 33:242734. doi: 10.1038/sj.npp.1301644

208. Kozono N, Ohtani A, Shiga T. Roles of the serotonin 5-HT4 receptor in dendrite formation of the rat hippocampal neurons in vitro. Brain Res. (2017) 1655:114-21. doi: 10.1016/j.brainres.2016.11.021

209. Schill Y, Bijata M, Kopach O, Cherkas V, Abdel-Galil D, Böhm K, et al. Serotonin 5-HT(4) receptor boosts functional maturation of dendritic spines via RhoA-dependent control of F-actin. Commun Biol. (2020) 3:76. doi: 10.1038/s42003-020-0791-x

210. Lecouflet P, Roux CM, Potier B, Leger M, Brunet E, Billard JM, et al. Interplay between 5-HT4 Receptors and GABAergic system within CA1 hippocampal synaptic plasticity. Cereb Cortex. (2021) 31:694701. doi: 10.1093/cercor/bhaa253

211. Wawra M, Fidzinski P, Heinemann U, Mody I, Behr J. 5-HT4-receptors modulate induction of long-term depression but not potentiation at hippocampal output synapses in acute rat brain slices. PLoS One. (2014) 9:e88085. doi: 10.1371/journal.pone.0088085

212. Cavaccini A, Gritti M, Giorgi A, Locarno A, Heck N, Migliarini S, et al. Serotonergic signaling controls input-specific synaptic plasticity at striatal circuits. Neuron. (2018) 98:801-816e807. doi: 10.1016/j.neuron.2018.04.008 
213. Huang YY, Kandel ER. 5-Hydroxytryptamine induces a protein kinase $\mathrm{A} /$ mitogen-activated protein kinase-mediated and macromolecular synthesis-dependent late phase of long-term potentiation in the amygdala. $J$ Neurosci. (2007) 27:3111-9. doi: 10.1523/JNEUROSCI.3908-06.2007

214. Kobayashi K, Ikeda Y, Sakai A, Yamasaki N, Haneda E, Miyakawa $\mathrm{T}$, et al. Reversal of hippocampal neuronal maturation by serotonergic antidepressants. Proc Natl Acad Sci U S A. (2010) 107:8434-9. doi: 10.1073/pnas.0912690107

215. Kobayashi K, Ikeda Y, Suzuki H. Behavioral destabilization induced by the selective serotonin reuptake inhibitor fluoxetine. Mol Brain. (2011) 4:12. doi: 10.1186/1756-6606-4-12

216. Amigo J, Diaz A, Pilar-Cuellar F, Vidal R, Martin A, Compan V, et al. The absence of 5-HT4 receptors modulates depression- and anxietylike responses and influences the response of fluoxetine in olfactory bulbectomised mice: Adaptive changes in hippocampal neuroplasticity markers and 5-HT1A autoreceptor. Neuropharmacology. (2016) 111:4758. doi: 10.1016/j.neuropharm.2016.08.037

217. Samuels BA, Mendez-David I, Faye C, David SA, Pierz KA, Gardier AM, et al. Serotonin $1 \mathrm{~A}$ and serotonin 4 receptors: essential mediators of the neurogenic and behavioral actions of antidepressants. Neuroscientist. (2016) 22:26-45. doi: 10.1177/1073858414561303

218. Lucas G, Rymar VV, Du J, Mnie-Filali O, Bisgaard C, Manta $\mathrm{S}$, et al. Serotonin(4) (5-HT(4)) receptor agonists are putative antidepressants with a rapid onset of action. Neuron. (2007) 55:712-25. doi: 10.1016/j.neuron.2007.07.041

219. Ward RP, Hamblin MW, Lachowicz JE, Hoffman BJ, Sibley DR, Dorsa DM. Localization of serotonin subtype 6 receptor messenger RNA in the rat brain by in situ hybridization histochemistry. Neuroscience. (1995) 64:110511. doi: 10.1016/0306-4522(94)00439-C

220. Gerard C, Martres MP, Lefèvre K, Miquel MC, Vergé D, Lanfumey $\mathrm{L}$, et al. Immuno-localization of serotonin 5-HT6 receptor-like material in the rat central nervous system. Brain Res. (1997) 746:207-19. doi: 10.1016/S0006-8993(96)01224-3

221. Roberts JC, Reavill C, East SZ, Harrison PJ, Patel S, Routledge C, et al. The distribution of 5-HT6 receptors in rat brain: an autoradiographic binding study using the radiolabelled 5-HT6 receptor antagonist [125I]SB-258585. Brain Res. (2002) 934:49-57. doi: 10.1016/S0006-8993(02)02360-0

222. King MV, Marsden CA, Fone KC. A role for the 5-HT(1A), 5-HT4 and 5-HT6 receptors in learning and memory. Trends Pharmacol Sci. (2008) 29:482-92. doi: 10.1016/j.tips.2008.07.001

223. Monsma FJ Jr, Shen Y, Ward RP, Hamblin MW, Sibley DR. Cloning and expression of a novel serotonin receptor with high affinity for tricyclic psychotropic drugs. Mol Pharmacol. (1993) 43:320-7.

224. Yun HM, Kim S, Kim HJ, Kostenis E, Kim JI, Seong JY, et al. The novel cellular mechanism of human 5-HT6 receptor through an interaction with Fyn. J Biol Chem. (2007) 282:5496-505. doi: 10.1074/jbc.M606215200

225. Riccioni T, Bordi F, Minetti P, Spadoni G, Yun HM, Im BH, et al. ST1936 stimulates cAMP, Ca2+, ERK1/2 and Fyn kinase through a full activation of cloned human 5-HT6 receptors. Eur J Pharmacol. (2011) 661:8-14. doi: 10.1016/j.ejphar.2011.04.028

226. Yun HM, Baik JH, Kang I, Jin C, Rhim H. Physical interaction of Jab1 with human serotonin 6 G-protein-coupled receptor and their possible roles in cell survival. J Biol Chem. (2010) 285:1001629. doi: 10.1074/jbc.M109.068759

227. Guadiana SM, Semple-Rowland S, Daroszewski D, Madorsky I, Breunig JJ, Mykytyn K, et al. Arborization of dendrites by developing neocortical neurons is dependent on primary cilia and type 3 adenylyl cyclase. J Neurosci. (2013) 33:2626. doi: 10.1523/JNEUROSCI.2906-12.2013

228. Lesiak AJ, Brodsky M, Cohenca N, Croicu AG, Neumaier JF. Restoration of physiological expression of 5-HT(6) receptor into the primary cilia of null mutant neurons lengthens both primary cilia and dendrites. Mol Pharmacol. (2018) 94:731-42. doi: 10.1124/mol.117.111583

229. Duhr F, Déléris P, Raynaud F, Séveno M, Morisset-Lopez S, Mannoury La Cour C, et al. Cdk5 induces constitutive activation of 5-HT6 receptors to promote neurite growth. Nat Chem Biol. (2014) 10:5907. doi: $10.1038 /$ nchembio.1547

230. Chaumont-Dubel S, Dupuy V, Bockaert J, Becamel C, Marin P. The 5-HT6 receptor interactome: New insight in receptor signaling and its impact on brain physiology and pathologies. Neuropharmacology. (2020) 172:107839. doi: 10.1016/j.neuropharm.2019.107839

231. Riccio O, Potter G, Walzer C, Vallet P, Szabo G, Vutskits L, et al. Excess of serotonin affects embryonic interneuron migration through activation of the serotonin receptor 6. Mol Psychiatry. (2009) 14:280 90. doi: 10.1038/mp.2008.89

232. Jacobshagen M, Niquille M, Chaumont-Dubel S, Marin P, Dayer A. The serotonin 6 receptor controls neuronal migration during corticogenesis via a ligand-independent Cdk5-dependent mechanism. Development. (2014) 141:3370-7. doi: 10.1242/dev.108043

233. Sun Z, Wang B, Chen C, Li C, Zhang Y. 5-HT6R null mutatrion induces synaptic and cognitive defects. Aging Cell. (2021) 20:e13369. doi: 10.1111/acel.13369

234. De Foubert G, O'neill MJ, Zetterstrom TS. Acute onset by 5-HT(6)-receptor activation on rat brain brain-derived neurotrophic factor and activityregulated cytoskeletal-associated protein mRNA expression. Neuroscience. (2007) 147:778-85. doi: 10.1016/j.neuroscience.2007.04.045

235. Dawson LA, Nguyen HQ, Li P. The 5-HT(6) receptor antagonist SB271046 selectively enhances excitatory neurotransmission in the rat frontal cortex and hippocampus. Neuropsychopharmacology. (2001) 25:6628. doi: 10.1016/S0893-133X(01)00265-2

236. West PJ, Marcy VR, Marino MJ, Schaffhauser H. Activation of the 5HT(6) receptor attenuates long-term potentiation and facilitates GABAergic neurotransmission in rat hippocampus. Neuroscience. (2009) 164:692701. doi: 10.1016/j.neuroscience.2009.07.061

237. Meffre J, Chaumont-Dubel S, Mannoury La Cour C, Loiseau F, Watson DJ, Dekeyne A, et al. 5-HT(6) receptor recruitment of mTOR as a mechanism for perturbed cognition in schizophrenia. EMBO Mol Med. (2012) 4:104356. doi: 10.1002/emmm.201201410

238. Wesołowska A, Nikiforuk A. Effects of the brain-penetrant and selective 5-HT6 receptor antagonist SB-399885 in animal models of anxiety and depression. Neuropharmacology. (2007) 52:1274-83. doi: 10.1016/j.neuropharm.2007.01.007

239. Smith GS, Barrett FS, Joo JH, Nassery N, Savonenko A, Sodums DJ, et al. Molecular imaging of serotonin degeneration in mild cognitive impairment. Neurobiol Dis. (2017) 105:33-41. doi: 10.1016/j.nbd.2017.05.007

240. Hedlund PB, Sutcliffe JG. Functional, molecular and pharmacological advances in 5-HT7 receptor research. Trends Pharmacol Sci. (2004) 25:4816. doi: 10.1016/j.tips.2004.07.002

241. Hedlund PB, Huitron-Resendiz S, Henriksen SJ, Sutcliffe JG. 5HT7 receptor inhibition and inactivation induce antidepressantlike behavior and sleep pattern. Biol Psychiatry. (2005) 58:8317. doi: 10.1016/j.biopsych.2005.05.012

242. Blattner KM, Canney DJ, Pippin DA, Blass BE. Pharmacology and therapeutic potential of the 5-HT(7) receptor. ACS Chem Neurosci. (2019) 10:89-119. doi: 10.1021/acschemneuro.8b00283

243. Shen Y, Monsma FJJr, Metcalf MA, Jose PA, Hamblin MW, Sibley DR. Molecular cloning and expression of a 5-hydroxytryptamine7 serotonin receptor subtype. J Biol Chem. (1993) 268:182004. doi: 10.1016/S0021-9258(17)46830-X

244. Gustafson EL, Durkin MM, Bard JA, Zgombick J, Branchek TA. A receptor autoradiographic and in situ hybridization analysis of the distribution of the 5-ht7 receptor in rat brain. Br J Pharmacol. (1996) 117:65766. doi: 10.1111/j.1476-5381.1996.tb15241.x

245. Adham N, Zgombick JM, Bard J, Branchek TA. Functional characterization of the recombinant human 5-hydroxytryptamine7(a) receptor isoform coupled to adenylate cyclase stimulation. J Pharmacol Exp Ther. (1998) 287:508-14

246. Scherer SL, Cain MD, Kanai SM, Kaltenbronn KM, Blumer KJ. Regulation of neurite morphogenesis by interaction between $\mathrm{R} 7$ regulator of $\mathrm{G}$ protein signaling complexes and $\mathrm{G}$ protein subunit $\mathrm{G} \alpha(13)$. J Biol Chem. (2017) 292:9906-18. doi: 10.1074/jbc.M116.771923

247. Katoh H, Aoki J, Yamaguchi Y, Kitano Y, Ichikawa A, Negishi M. Constitutively active Galpha12, Galpha13, and Galphaq induce Rhodependent neurite retraction through different signaling pathways. J Biol Chem. (1998) 273:28700-7. doi: 10.1074/jbc.273.44.28700

248. Nürnberg A, Braüer AU, Wettschureck N, Offermanns S. Antagonistic regulation of neurite morphology through Gq/G11 and G12/G13. 
J Biol Chem. (2008) 283:35526-31. doi: $10.1074 /$ jbc.M8049 72200

249. Holst K, Guseva D, Schindler S, Sixt M, Braun A, Chopra H, et al. The serotonin receptor 5-HT7R regulates the morphology and migratory properties of dendritic cells. J Cell Sci. (2015) 128:286680. doi: $10.1242 /$ jcs. 167999

250. Speranza L, Giuliano T, Volpicelli F, De Stefano ME, Lombardi L, Chambery A, et al. Activation of 5-HT7 receptor stimulates neurite elongation through mTOR, Cdc42 and actin filaments dynamics. Front Behav Neurosci. (2015) 9:62. doi: 10.3389/fnbeh.2015.00062

251. Bijata M, Labus J, Guseva D, Stawarski M, Butzlaff M, Dzwonek $\mathrm{J}$, et al. Synaptic remodeling depends on signaling between serotonin receptors and the extracellular matrix. Cell Rep. (2017) 19:1767-82. doi: 10.1016/j.celrep.2017.05.023

252. Speranza L, Labus J, Volpicelli F, Guseva D, Lacivita E, Leopoldo M, et al. Serotonin 5-HT7 receptor increases the density of dendritic spines and facilitates synaptogenesis in forebrain neurons. J Neurochem. (2017) 141:647-61. doi: 10.1111/jnc. 13962

253. Olusakin J, Moutkine I, Dumas S, Ponimaskin E, Paizanis E, Soiza-Reilly $M$, et al. Implication of 5-HT7 receptor in prefrontal circuit assembly and detrimental emotional effects of SSRIs during development. Neuropsychopharmacology. (2020) 45:2267-77. doi: 10.1038/s41386-020-0775-z

254. Sandvig I, Augestad IL, Håberg AK, Sandvig A. Neuroplasticity in stroke recovery. The role of microglia in engaging and modifying synapses and networks. Eur J Neurosci. (2018) 47:1414-28. doi: 10.1111/ejn. 13959

255. Patel Y, Parker N, Shin J, Howard D, French L, Thomopoulos SI, et al. Virtual histology of cortical thickness and shared neurobiology in 6 psychiatric disorders. JAMA Psychiatry. (2021) 78:47-63. doi: 10.1001/jamapsychiatry.2020.2694

256. Vahid-Ansari F, Albert PR. chronic fluoxetine induces activity changes in recovery from poststroke anxiety, depression, and cognitive impairment. Neurotherapeutics. (2018) 15:200-15. doi: 10.1007/s13311-017-0590-3

257. Underwood MD, Kassir SA, Bakalian MJ, Galfalvy H, Mann JJ, Arango V. Neuron density and serotonin receptor binding in prefrontal cortex in suicide. Int J Neuropsychopharmacol. (2012) 15:435-47. doi: 10.1017/S1461145711000691

258. Underwood MD, Kassir SA, Bakalian MJ, Galfalvy H, Dwork AJ, Mann JJ, et al. Serotonin receptors and suicide, major depression, alcohol use disorder and reported early life adversity. Transl Psychiatry. (2018) 8:279. doi: 10.1038/s41398-018-0309-1

259. Rolls ET, Cheng W, Feng J. The orbitofrontal cortex: reward, emotion and depression. Brain Commun. (2020) 2:fcaa196. doi: 10.1093/braincomms/fcaa196

260. Drevets WC. Orbitofrontal cortex function and structure in depression. Ann N Y Acad Sci. (2007) 1121:499-527. doi: 10.1196/annals. 1401.029
261. Hahn A, Haeusler D, Kraus C, Hoflich AS, Kranz GS, Baldinger P, et al. Attenuated serotonin transporter association between dorsal raphe and ventral striatum in major depression. Hum Brain Mapp. (2014) 35:385766. doi: 10.1002/hbm. 22442

262. Bhagwagar Z, Murthy N, Selvaraj S, Hinz R, Taylor M, Fancy S, et al. 5HTT binding in recovered depressed patients and healthy volunteers: a positron emission tomography study with [11C]DASB. Am J Psychiatry. (2007) 164:1858-65. doi: 10.1176/appi.ajp.2007.06111933

263. Meyer JH, Houle S, Sagrati S, Carella A, Hussey DF, Ginovart N, et al. Brain serotonin transporter binding potential measured with carbon 11labeled DASB positron emission tomography: effects of major depressive episodes and severity of dysfunctional attitudes. Arch Gen Psychiatry. (2004) 61:1271-9. doi: 10.1001/archpsyc.61.12.1271

264. Lanzenberger R, Kranz GS, Haeusler D, Akimova E, Savli M, Hahn A, et al. Prediction of SSRI treatment response in major depression based on serotonin transporter interplay between median raphe nucleus and projection areas. Neuroimage. (2012) 63:874-81. doi: 10.1016/j.neuroimage.2012.07.023

265. Ananth M, Bartlett EA, Delorenzo C, Lin X, Kunkel L, Vadhan NP, et al. Prediction of lithium treatment response in bipolar depression using 5HTT and 5-HT1A PET. Eur J Nucl Med Mol Imaging. (2020) 47:241728. doi: 10.1007/s00259-020-04681-6

266. Beliveau V, Svarer C, Frokjaer VG, Knudsen GM, Greve DN, Fisher PM. Functional connectivity of the dorsal and median raphe nuclei at rest. Neuroimage. (2015) 116:187-95. doi: 10.1016/j.neuroimage.2015.04.065

267. Weinstein JJ, Rogers BP, Taylor WD, Boyd BD, Cowan RL, Shelton KM, et al. Effects of acute tryptophan depletion on raphe functional connectivity in depression. Psychiatry Res. (2015) 234:164-71. doi: 10.1016/j.pscychresns.2015.08.015

Conflict of Interest: The authors declare that the research was conducted in the absence of any commercial or financial relationships that could be construed as a potential conflict of interest.

Publisher's Note: All claims expressed in this article are solely those of the authors and do not necessarily represent those of their affiliated organizations, or those of the publisher, the editors and the reviewers. Any product that may be evaluated in this article, or claim that may be made by its manufacturer, is not guaranteed or endorsed by the publisher.

Copyright (C) 2021 Vahid-Ansari and Albert. This is an open-access article distributed under the terms of the Creative Commons Attribution License (CC BY). The use, distribution or reproduction in other forums is permitted, provided the original author(s) and the copyright owner(s) are credited and that the original publication in this journal is cited, in accordance with accepted academic practice. No use, distribution or reproduction is permitted which does not comply with these terms. 